\title{
Overcoming Multidrug Resistance and Biofilms of Pseudomonas aeruginosa with a Single Dual-Function Potentiator of $\beta$-Lactams
}

\author{
Anh K. Lam ${ }^{\dagger}$, Hannah Panlilio ${ }^{\dagger}$, Jennifer Pusavat ${ }^{\dagger}$, Cassandra L. Wouters, Erika L. Moen \\ Department of Chemistry and Biochemistry, Stephenson Life Sciences Research Center, \\ University of Oklahoma, Norman, Oklahoma 73019, United States \\ Charles V Rice ${ }^{*}$ \\ Department of Chemistry and Biochemistry, Stephenson Life Sciences Research Center, \\ University of Oklahoma, Norman, Oklahoma 73019, United States;
}

\begin{abstract}
Clinicians prescribe hundreds of millions of $\beta$-lactam antibiotics to treat the majority of patients presenting with bacterial infections. Patient outcomes are positive unless resistant bacteria, such as Pseudomonas aeruginosa ( $P$. aeruginosa), are present. $P$. aeruginosa has both intrinsic and acquired antibiotic resistance, making clinical management of infection a real challenge, particularly when these bacteria are sequestered in biofilms. These problems would be alleviated if, upon the initial presentation of bacterial infection symptoms, clinicians were able to administer an antibiotic that kills both susceptible and otherwise resistant bacteria and eradicates biofilms. As the most common class of antibiotics, $\beta$-lactams could be used in a new drug if the leading causes of $\beta$ lactam antibiotic resistance, permeation barriers from lipopolysaccharide, efflux pumps, and $\beta$ lactamase enzymes, were also defeated. Against $P$. aeruginosa and their biofilms, the potency of $\beta$ lactam antibiotics is restored with $600 \mathrm{Da}$ branched polyethylenimine (600 Da BPEI).

Checkerboard assays using microtiter plates demonstrate the potentiation of piperacillin, cefepime, Meropenem, and erythromycin antibiotics. Growth curves demonstrate that only a combination of 600 Da BPEI and piperacillin produces growth inhibition antibiotic resistant $P$. aeruginosa.

Scanning electron microscopy (SEM) was used to confirm that the combination treatment leads to abnormal $P$. aeruginosa morphology. Data collected with isothermal titration calorimetry and fluorescence spectroscopy demonstrate a mechanism of action in which potentiation at low concentrations of $600 \mathrm{Da}$ BPEI reduces diffusion barriers from lipopolysaccharides without disrupting the outer membrane itself. Coupled with the ability to overcome a reduction in antibiotic activity created by biofilm exopolymers, targeting anionic sites on lipopolysaccharides
\end{abstract}

Supporting Information

The Supporting Information is available free of charge at https://pubs.acs.org/doi/10.1021/acsinfecdis.9b00486.

Antibiotic susceptibility, MIC and FICI values, checkerboard assays, incubation of PA BAA-47 cells at high cell density with resazurin, uptake of $\mathrm{H} 33342$, calcium ions occupying LPS binding sites, an illustration of using excess metal ions to occupy the anionic site of LPS and prevent the binding of $600 \mathrm{Da}$ BPEI, ITC data, illustration of the dye $1-N$-phenylnaphthylamine, HPLC chromatogram, mass spectrum of $600 \mathrm{Da}$ BPEI, FTIR spectrum (PDF)

Corresponding Author: Charles V. Rice - Department of Chemistry and Biochemistry, Stephenson Life Sciences Research Center, University of Oklahoma, Norman, Oklahoma 73019, United States; Phone: 405-325-5831; rice@ ou.edu; Fax: 405-325-6111.

Author Contributions A.K.L., H.P., and J.P. contributed equally to the manuscript. The manuscript was written through

contributions of all authors. All authors have given approval to the final version of the manuscript.

Notes

The authors declare no competing financial interest. 
and biofilm exopolysaccharides with the same compound provides new opportunities to counter the rise of multidrug-resistant infections.

\section{GRAPHICAL ABSTRACT}
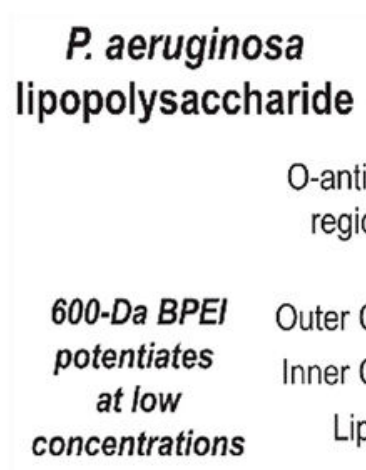

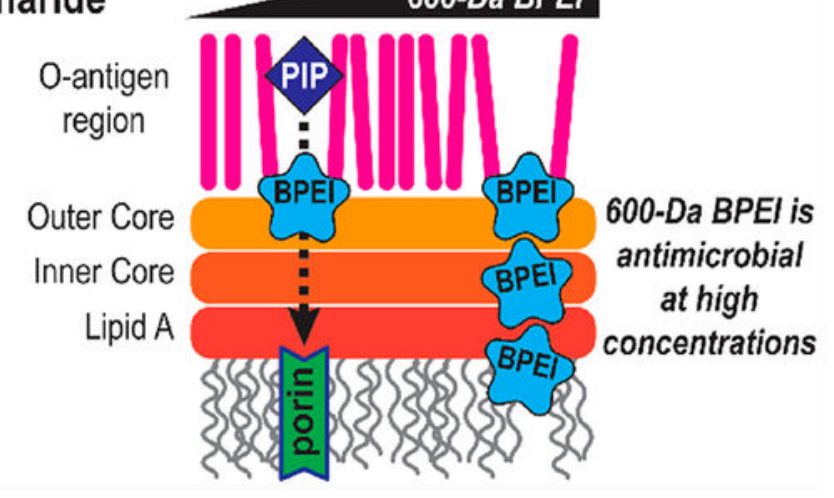

\section{Keywords}

Pseudomonas aeruginosa; antibiotic resistance; biofilm; piperacillin; potentiation; branched polyethylenimine

Pseudomonas aeruginosa ( $P$. aeruginosa) is a Gram-negative bacterium for which antibiotic therapy is useful, but resistant strains often result in severe chronic infections. It poses a great risk to public health because its outer membrane, composed of lipopolysaccharides (LPSs), is a barrier to antibiotic influx (Figure 1). P. aeruginosa causes severe pneumonia, blood-stream infections, respiratory tract infections (RTIs), urinary tract infections (UTIs), skin infections, and eye infections. Prominent in burn units, $P$. aeruginosa is of particular concern in wound healing ${ }^{1-3}$ because it produces biofilms that are impenetrable to antibiotics, leading to chronic infections. ${ }^{4-6}$ Biofilms sequester bacterial pathogens and protect them from antimicrobial attack. They are associated with ear infections, chronic sinus infections, abrasions, wound infections, burns, or chronic health problems. For example, infections of diabetic wounds and foot ulcers often become chronic because they stall in the suboptimal inflammatory phase of healing perpetuated by biofilms. ${ }^{7-10} P$. aeruginosa infections and their biofilms create serious health issues, and the threat to patient survival increases when the bacterium is multidrug-resistant $P$. aeruginosa (MDR-PA). ${ }^{11-14}$

Biofilms and antibiotic resistance create substantial technological hurdles to patient treatment. ${ }^{15}$ This presents a significant and critical need for a way to counteract them. Existing drugs and regimens are coupled with potentiators that overcome antibiotic resistance or biofilms. ${ }^{16}$ However, it is possible to develop a single compound that disables biofilms and combats antibiotic resistance. As a multipurpose potentiator, $600 \mathrm{Da}$ branched polyethylenimine (BPEI) can disable resistance and dissolve biofilms. We have used $600 \mathrm{Da}$ BPEI to confront the biofilm directly and disrupt the protective exopolymer substance (EPS) network of methicillin-resistant staphylococci while simultaneously counteracting $\beta$-lactam 
resistance mechanisms. ${ }^{17-20}$ In this report, we show that 600 Da BPEI also disables MDR mechanisms and biofilms in P. aeruginosa obtained from the American Type Culture Collection (ATCC) and antibiotic resistant clinical isolates.

\section{RESULTS AND DISCUSSION}

While examining BPEI potentiation of $\beta$-lactams against multidrug-resistant $P$. aeruginosa, checkerboard assays demonstrated synergistic effects between $600 \mathrm{Da}$ BPEI and $\beta$-lactam antibiotics against two laboratory strains of $P$. aeruginosa, ATCC 27853 and ATCC

BAA- $47,{ }^{21}$ and several multidrug-resistant (MDR) clinical isolates from patients at the University of Oklahoma College of Medicine. The minimum inhibitory concentrations (MICs) of $600 \mathrm{Da}$ BPEI and piperacillin against these strains were determined and used to calculate the fractional inhibitory concentration index (FICI). ${ }^{18,22}$ An FICI lower than 0.5 indicates synergy, while an FICI between 0.5 and 1 represents additivity. The $600 \mathrm{Da}$ BPEI MICs against $P$. aeruginosa ATCC 27853 and ATCC BAA-47 and 5 clinical isolates varied from 8 to $64 \mu \mathrm{g} \mathrm{mL}^{-1}$ (Table 1 and Figure 2). For the $\beta$-lactam antibiotic piperacillin, resistance in $P$. aeruginosa is defined by USCAST as a minimum inhibitory concentration (MIC) $\geq 8 \mu \mathrm{g} / \mathrm{mL} .{ }^{23}$ As shown in Table 1, the ATCC strains were susceptible to piperacillin, yet the clinical isolates exhibited strong piperacillin resistance. Using checkerboard assays (Figure 2), the presence of 600 Da BPEI lowered the MIC of piperacillin against MDR-PA isolate OU1 and the other tested strains (Figures S1 and S2). The clinical isolates are multidrug-resistant, and all were rendered susceptible to piperacillin with the exception of OU15. Fortunately, we were able to restore susceptibility of OU15 to cefepime, whose 32 $\mu \mathrm{g} / \mathrm{mL}$ MIC (resistant) is lowered to $0.5 \mu \mathrm{g} / \mathrm{mL}$ with $16 \mu \mathrm{g} / \mathrm{mL} 600$ Da BPEI (Figure S3). Cefepime resistance in OU19 and OU22 (MIC $=64$ and $128 \mu \mathrm{g} / \mathrm{mL}$, respectively) is also eliminated with $16 \mu \mathrm{g} / \mathrm{mL} 600$ Da BPEI (MIC lowered to $8 \mu \mathrm{g} / \mathrm{mL}$ for both strains, Figure S3).

The data in Table 1 were collected without tazobactam, a $\beta$-lactamase inhibitor, suggesting that enzymatic activity cannot maintain this form of $\beta$-lactam resistance. Perhaps the intracellular piperacillin concentration is sufficient to overcome losses from $\beta$-lactamase hydrolysis. Sublethal concentrations of piperacillin become bacteriostatic when combined with sublethal concentrations of $600 \mathrm{Da}$ BPEI (Figure 3). Within $24 \mathrm{~h}$, the untreated control group grew to an $\mathrm{OD}_{600}$ of 2 , as did the individual treatment of either $600 \mathrm{Da}$ BPEI or piperacillin alone, indicating that these concentrations are insufficient to kill the bacteria. Only the combination $600 \mathrm{Da} \mathrm{BPEI}+$ piperacillin treatment could effectively stop its growth, highlighting the restorative value of $600 \mathrm{Da}$ BPEI on $\beta$-lactam antibiotic efficacy.

As described below, $600 \mathrm{Da}$ BPEI does not inhibit efflux pumps. However, there are concentration dependent effects of $600 \mathrm{Da}$ BPEI, which has antibiotic properties at high concentrations. At lower concentrations used for $\beta$-lactam potentiation, the mechanism of action likely involves creating new avenues of access through the LPS layer to increase intracellular antibiotic concentrations and overcome $\beta$-lactamase enzymes and efflux pumps. At slightly higher concentrations needed to potentiate erythromycin, $600 \mathrm{Da}$ BPEI causes slight perturbations to the outer membrane. However, previous data collected with 
fluorescence microscopy show that sub-MIC concentrations of 600 Da BPEI do not accumulate within $E$. coli cells. ${ }^{18}$

The ability of improve $\beta$-lactam efficacy at low concentration occurs because the crosslinked network of LPS presents a barrier to the free diffusion of antibiotics. The outer membrane of $P$. aeruginosa contains numerous $\beta$-barrel proteins among the alkyl chains of the phospholipid and LPS leaflets. These porins allow for the influx of $\beta$-lactam antibiotics $^{24}$ between the extracellular milieu and the periplasmic space. ${ }^{25}$ However, the inner-core, outer-core, and O-antigen regions of LPS slow the uptake of $\beta$-lactams. ${ }^{26} \mathrm{Ca}^{2+}$ and $\mathrm{Mg}^{2+}$ ions stabilize these anionic regions, and we posit that $600 \mathrm{Da}$ BPEI also binds to these sites causing localized reduction in the diffusion barrier. This was evaluated by determining if $600 \mathrm{Da}$ BPEI binds to LPS and by performing permeation assays that monitor the intracellular concentration of probe molecules.

Isothermal titration calorimetry (ITC) directly measures the enthalpy of molecular binding interactions. Here, it was used to confirm interactions between 600 Da BPEI and $P$. aeruginosa LPS. The raw thermogram data obtained when 600 Da BPEI was titrated into LPS are shown in Figure 4. The peaks resulting from each injection were exothermic and gradually became smaller, suggesting that the LPS became increasingly saturated with 600 Da BPEI. These titration data are converted to an isotherm (Figure 4). The negative $\Delta H$ values indicate exothermic binding. This binding profile indicates that there was an interaction between 600 Da BPEI and LPS, which is likely through electrostatic interactions between cationic amines of $600 \mathrm{Da}$ BPEI and anionic phosphates and carboxylate groups of LPS molecules. The $x$-axis of the thermogram is used to reveal the molar ratio of each species if their respective molecular weights are known. Using an LPS molecular weight of $20 \mathrm{kDa},{ }^{27}$ the molar ratio of $\sim 2.5$ indicates several molecules of $600 \mathrm{Da}$ BPEI can bind to a single LPS molecule. In the bacterial outer membrane environment, this would allow for multiple 600 Da BPEI binding events with the inner-core, outer-core, O-antigen, and lipid A regions. The inner-core and outer-core polysaccharides of LPS contain phosphate and carboxylate groups that attract metal ions. These binding sites, and the corresponding metal ions, are located 1-2 nm away from the membrane. ${ }^{26,28,29}$ Likewise, the LPS O-antigen region contains carboxylates that bind metal ions. ${ }^{30,31}$ The metal ions form bridges between adjacent LPS molecules, and this network presents a barrier to the passive diffusion of hydrophilic compounds, including $\beta$-lactam antibiotics. However, the ITC data show that cationic $600 \mathrm{Da}$ BPEI binds with these anionic sites of LPS. This would cause localized disruption of the LPS-metal network and creates new avenues of access for $\beta$-lactams to reach porin transporters imbedded in the membrane lipid tails. In this manner, 600 Da BPEI increases intracellular concentration of $\beta$-lactam antibiotics but does not need to cross the membrane itself to be effective (Figure 5).

Although 600 Da BPEI may increase antibiotic influx, it may also hinder efflux pumps. This can be tested with a fluorescence assay. Using a $P$. aeruginosa PAO1 strain that is multidrugresistant, ${ }^{32}$ bacterial cells were exposed to the fluorescent probe $\mathrm{H} 33342$ that is also a substrate for efflux pumps. Fluorescence spectroscopy data measure its accumulation within the cells (Figure 6). The fluorescence intensity of H33342 is significantly enhanced when bound to the cell membranes and bacterial DNA, leveling off at the maximum intracellular 
cellular concentration of $\mathrm{H} 33342$. The addition of $600 \mathrm{Da}$ BPEI increased its fluorescence intensity 4-fold. The increase of $\mathrm{H} 33342$ intracellular concentration suggests that $600 \mathrm{Da}$ BPEI either enhanced the passive diffusion or inactivated the active efflux system. Using this strain's efflux-deficient mutant, $\mathrm{Pa} \Delta 3,{ }^{32}$ the fluorescence intensity increases further. This shows that $600 \mathrm{Da}$ BPEI is not blocking efflux processes. If BPEI was blocking efflux, the intensities would be the same because the efflux pump target is absent in $\mathrm{Pa} \Delta 3$ cells and 600 Da BPEI would not influence the intracellular concentration in this mutant strain. However, the probe concentration does increase in the presence of $600 \mathrm{Da} \mathrm{BPEI}$, and thus, the effect is attributed to increased drug influx that allows Pseudomonas cells to take up more of the fluorescent molecule.

A noteworthy consideration is that the concentration of BPEI $(128 \mu \mathrm{g} / \mathrm{mL})$ used in fluorescence assays is higher than that needed for potentiation or MICs because the cell density needed for a detectable fluorescence signal was much higher. All fluorescence studies used a cell density of $\sim 6 \times 10^{9} \mathrm{CFU} / \mathrm{mL}$, while checkerboard assays only inoculated a cell density of $5 \times 10^{5} \mathrm{CFU} / \mathrm{mL}$. Therefore, an amount of $128 \mu \mathrm{g} / \mathrm{mL}$ BPEI for fluorescence assays is considered sublethal, which is tested and confirmed by resazurin assays (Figure S6). The reduction of resazurin to resorufin occurs via cellular metabolism and thus is an excellent reporter of cell viability. ${ }^{33}$ As shown in Figure S6, $128 \mu \mathrm{g} / \mathrm{mL} 600$ Da BPEI for this large cell density $\left(\sim 6 \times 10^{9} \mathrm{CFU} / \mathrm{mL}\right)$ is not lethal but causes a $12.5 \%$ reduction in cell viability. However, resazurin fluorescence values for cells treated with polymyxin B are near background levels, indicating that these cells are dead. These results have several important impacts. First, the cells in the fluorescence assays are viable, and thus, drug influx and efflux processes control the intracellular concentration rather than widespread disruption of the outer membrane that leads to cell lysis. Second, $600 \mathrm{Da}$ BPEI is less toxic to $P$. aeruginosa BAA-47 cells than polymyxin $\mathrm{B}$, which is also toxic toward eukaryotic cells. The biocompatibility of $600 \mathrm{Da}$ BPEI has been demonstrated against mouse fibroblast cells, ${ }^{18}$ immortal human cell lines, ${ }^{17}$ and primary human kidney epithelial cells. ${ }^{17}$ Finally, at sublethal concentrations, $600 \mathrm{Da}$ BPEI is not disrupting cellular energy metabolism because resazurin reduction occurs via the conversion of $\mathrm{NADH} / \mathrm{H}^{+}$to $\mathrm{NAD}^{+}$, and thus, outer membrane energetics are also likely to be unaffected.

The ability of $600 \mathrm{Da}$ BPEI to increase H33342 influx is concentration dependent (Figure 7). In the PAO1 cells, the competition between influx and efflux results in a gradual increase in H33342 concentration over time. The data points for $\mathrm{H} 33342$ concentration in cells treated with 16 and $32 \mu \mathrm{g} / \mathrm{mL} 600 \mathrm{Da}$ BPEI overlap, whereas the data for $64 \mu \mathrm{g} / \mathrm{mL} 600 \mathrm{Da}$ BPEI is slightly higher and $128 \mu \mathrm{g} / \mathrm{mL} 600$ Da BPEI gives the highest reading (Figure 7A). As shown in Figure S6, these concentrations are not lethal toward a high density of $P$. aeruginosa cells. However, the presence of efflux creates a multifactor condition that complicates the interpretation of biochemical mechanisms. ${ }^{34}$ Thus, this experiment was repeated with the efflux-deficient mutant $\mathrm{Pa} \Delta 3$ (Figure 7B). Inspection of the data reveals that the increase in $\mathrm{H} 33342$ concentration over time is not linear but rather exponential in nature, in agreement with a recent kinetic analysis. ${ }^{34}$ By plotting the $\ln [\mathrm{H} 33342]$ versus time, it is apparent that the rate of influx is slowest with the lowest concentration of $600 \mathrm{Da}$ BPEI (Figure 8). Thus, a faster rate of influx at a higher concentration of $600 \mathrm{Da}$ BPEI is due to binding with additional anionic sites of the $\mathrm{O}$-antigen, outer-core, and inner-core 
regions. As illustrated in Figure S7, low concentrations of 600 Da BPEI limit binding to the outermost regions of LPS. As the BPEI concentration is increased, additional binding sites are occupied until, at levels approaching the MIC, $600 \mathrm{Da}$ BPEI binds to lipid A. This scenario allows sub-MIC concentrations of 600 Da BPEI to open the LPS network and facilitate diffusion of the H33342 dye. This model also explains the high MIC of $600 \mathrm{Da}$ BPEI $(16-64 \mu \mathrm{g} / \mathrm{mL})$, whereas only a fraction of this amount is required for $\beta$-lactam potentiation (Table 1). The increased piperacillin MIC in the clinical isolates may be due to overexpression and/or novel $\beta$-lactamases, deletion or reduced expression of specific porins, mutations within the porin channel that hinder $\beta$-lactam transport, or efflux pumps that are overexpressed. Regardless, $600 \mathrm{Da}$ BPEI can restore piperacillin susceptibility in the clinical isolates, causing a considerable reduction of piperacillin MICs.

With regards to other antibiotics, such as Meropenem and erythromycin, the situation is more complicated. For the clinical isolates OU15, OU19, and OU22, the Meropenem MIC was $16-64 \mu \mathrm{g} / \mathrm{mL}$, but there was no synergy with $600 \mathrm{Da}$ BPEI, only additivity that caused a modest reduction in MIC values (Figure S4). Likewise, the erythromycin MICs were 256 $\mu \mathrm{g} / \mathrm{mL}$ for these 3 isolates, and $600 \mathrm{Da}$ BPEI exhibited synergy but only reduced the erythromycin MIC by a factor of 4 (Figure S5). Recognizing that 600 Da BPEI increases the influx of $\mathrm{H} 33342$ in a concentration dependent manner and that the rate of influx also increases with concentration, it is possible to understand the antibiotic potentiation data. When $600 \mathrm{Da}$ BPEI at 1/4th of its MIC value is added, the diffusion barrier of LPS is reduced. This reduces the piperacillin MIC from over 256 to $1-4 \mu \mathrm{g} / \mathrm{mL}$. The potentiation effect on Meropenem is lower, which may be due to hindered porin transport. For erythromycin, reducing the MIC from 256 to $64 \mu \mathrm{g} / \mathrm{mL}$ occurs in the presence of $16 \mu \mathrm{g} / \mathrm{mL}$ $600 \mathrm{Da}$ BPEI. As with H33342, erythromycin crosses membranes by passive diffusion, and thus, at $16 \mu \mathrm{g} / \mathrm{mL}, 600 \mathrm{Da}$ BPEI is reducing diffusion barriers from LPS rather than disrupting the membrane itself. Membrane disruption occurs at the MIC of BPEI, $64 \mu \mathrm{g} / \mathrm{mL}$.

The ability of $600 \mathrm{Da}$ BPEI to potentiate $\beta$-lactams occurs through electrostatic interactions with LPS anionic sites that also attract metal ions. In the absence of metal ions, the anionic LPS molecules would repel each other and disperse into the extracellular milieu. Instead, $\mathrm{Mg}^{2+}$ ions allow the formation of a stable membrane layer by binding to phosphate groups of the lipid A moiety and forming electrostatic bridges between adjacent LPS molecules. Additional phosphate and carboxylate groups are found on heptose and ketodeoxyoctulosonate units of the core oligosaccharides. ${ }^{25,26,28,30}$ The O-antigen groups are decorated with hydroxyls and the occasional carboxylate group that can attract metal ions. ${ }^{30}$ These anionic LPS sites are critical resistance mechanisms. ${ }^{35}$ As Hancock and coworkers found, various compounds (including cationic species) disrupt the LPS's $\mathrm{Mg}^{2+}$ chelation and increase $P$. aeruginosa's susceptibility to antibacterial agents. ${ }^{36-38}$ The primary amines on $600 \mathrm{Da}$ BPEI enable it to bind with phosphate and carboxylate groups, and its flexible branches facilitate structural reorganization to reach multiple binding sites within the inner- and outer-core regions of LPS and span adjacent LPS molecules. The ability of $600 \mathrm{Da}$ BPEI to influence membrane permeability, such as the influx of H33342 (Figure 6), readily occurs at sublethal concentrations (Figure S8). However, there is a dependence on divalent metal ions. 600 Da BPEI weakens the LPS network that otherwise hinders drug uptake. Conversely, adding $\mathrm{Mg}^{2+}$ and $\mathrm{Ca}^{2+}$ ions stabilize the LPS to strengthen 
the barrier. This competition is demonstrated in Figure 9. Here, $2 \mathrm{mM} \mathrm{Mg}^{2+}$ ions were exposed to BAA-47 cells that were treated with 600 Da BPEI. The lower fluorescence of H33342 indicates that its influx has been slowed by metal ions that reverse the weakening of the LPS diffusion barrier, but this process is insufficient to completely dislodge $600 \mathrm{Da}$ BPEI from the phosphate/carboxylate binding sites and restore the LPS barrier to its full strength. Similar effects are observed for $\mathrm{Ca}^{2+}$ ions (Figure S8). For both metal ions, the order of addition affects the data. When the cells are treated with $600 \mathrm{Da}$ BPEI first and metal ions second, the $\mathrm{H} 33342$ intensity reaches a magnitude lower than the BPEI-only data but greater than that for cells only (open squares, Figure 9). However, if the metal ions are added first, the addition of 600 Da BPEI does not affect the $\mathrm{H} 33342$ intensity (closed squares, Figure 9). One possible explanation is that the anionic sites of LPS are fully occupied by metals, and thus, 600 Da BPEI cannot bind and promote the diffusion of the fluorescent dye (Figure S9). The mechanism for $600 \mathrm{Da}$ PBEI is different from other agents that weaken the LPS barrier by chelating metal ions, such as ethylenediamine tetraacetic acid (EDTA). Using data collected with ITC, 600 Da BPEI will chelate $\mathrm{Cu}^{2+}$ ions (Figure $\mathrm{S} 10$ ), but there is no interaction with $\mathrm{Mg}^{2+}$ or $\mathrm{Ca}^{2+}$ ions (Figure $\mathrm{S} 10 \mathrm{~B}, \mathrm{C}$ ).

The importance of metal ions in the antibiotic mechanism is well established, and thus, the Clinical and Laboratory Standards Institute (CLSI) guidelines for MIC testing specify the use of cationic-adjusted MHB (CAMHB). ${ }^{39}$ These protocols were followed for the growth assay experiments, and thus, under standard conditions, metal ions in CAMHB do not interfere with potentiation by 600 Da BPEI. These data suggest that, when cells are grown in CAMHB, the array of metal binding sites within the outer membrane LPS are not fully occupied. This provides an opportunity for $600 \mathrm{Da}$ BPEI to establish its own electrostatic interactions with the LPS and create new avenues of access for drugs to reach the membrane. This effect is concentration dependent. Lower amounts of 600 Da BPEI facilitate the uptake of piperacillin, a $517 \mathrm{~g} / \mathrm{mol} \beta$-lactam antibiotic that is readily transported to the cytoplasm by transmembrane porins. However, larger amounts of $600 \mathrm{Da}$ BPEI are needed to create the larger avenues of access for erythromycin, a $734 \mathrm{~g} / \mathrm{mol}$ macrolide that reaches the cytoplasm via passive diffusion.

In addition to weakening the LPS barrier to diffusion, 600 Da BPEI could be increasing drug influx by changing the permeation properties of the outer membrane and perhaps even disrupting the outer membrane lipid bilayer itself. While this hypothesis is not supported with the cell viability data in Figure S6, the phenomenon can be tested with the fluorescence probe molecule 1- $N$-phenylnaphthylamine (NPN) that localizes to the lipid membrane and fluoresces when bound to phospholipids. ${ }^{40-42}$ In the absence of agents that disrupt the cell membrane, fluorescence is weak from barriers to passive diffusion. However, when the outer membrane is breached, NPN can easily reach phospholipids of the inner leaflet and fluorescence intensity increases. As shown in Figure 10, NPN fluorescence reaches value of about 13000 units in a sample of $\sim 6 \times 10^{9} \mathrm{CFU} / \mathrm{mL} P$. aeruginosa BAA-47 cells. The treatment of a similar sample with $64 \mu \mathrm{g} / \mathrm{mL}$ polymyxin B causes a 2.7 -fold increase in fluorescence intensity, which occurs via insertion of polymyxin B into the membrane via self-promoted uptake. ${ }^{36}$ However, 64 and $128 \mu \mathrm{g} / \mathrm{mL} 600$ Da BPEI cause a 1.5-fold increase in NPN fluorescence, and we know that these concentrations of 600 Da BPEI are nonlethal (Figure S6). Thus, we suggest that 600 Da BPEI is weakening the LPS diffusion barrier, but 
it is not intercalating into the membrane bilayer that otherwise would lead to a higher increase in NPN fluorescence intensity (Figure S11).

The ability of 600 Da BPEI to weaken the LPS diffusion barrier without causing widespread membrane disruption and cell lysis is shown with scanning electron microscopy (SEM). SEM was conducted to examine the morphology and the possible effects of 600 Da BPEI on bacterial cell division. $P$. aeruginosa BAA-47 cells were grown to mid-log phase and subjected to four separate treatments: untreated control, sublethal 600 Da BPEI, sublethal piperacillin, and a combination of $600 \mathrm{Da}$ BPEI and piperacillin, each at sublethal combinations. SEM images of the untreated control sample (Figure 11A) show that all the cells have a regular rod shape with a normal size distribution and division septa are clear. BPEI treated cells (Figure 11B) are longer, and cell-divided septa show a gradual narrowing rather than a sharper interface. The piperacillin treated cells (Figure 11C) are longer, have signs of a well-formed division septum, and exhibit signs of cell wall weakening without bursting. The combination of BPEI + piperacillin caused the treated cells (Figure 11D) to rupture (Figure 11E), and they show extreme distortions in shape (Figure 11F). The extreme distortions in both size ( 20 times longer than untreated control cells) and shape without obvious division septa suggests that the recruiting, activity, and/or competence of bacterial divisome ${ }^{43,44}$ components is hindered. These cellular morphological changes aid in explaining the killing properties of the BPEI + piperacillin combination, although the concentration of each compound is sublethal on their own.

Biofilms are accumulations of microorganisms embedded in a polysaccharide matrix known as extracellular polymeric substance (EPS), which protects the bacteria from antimicrobial agents. ${ }^{9,10}$ Current in-patient treatments include cleansing the wound, debridement, maintaining a moist tissue environment, and when possible, eliminating the underlying factors that contributed to poor wound healing. ${ }^{45}$ BPEI confronts the biofilm directly by disrupting the protective EPS. As shown in Figure 12, biofilms of $P$. aeruginosa BAA-47 create additional barriers that require $256 \mu \mathrm{g} / \mathrm{mL}$ piperacillin to kill the bacteria. This minimum biofilm eradication concentration (MBEC) is significantly higher than the MIC of $4 \mu \mathrm{g} / \mathrm{mL}$. Likewise, the MBEC of 600 Da BPEI is $512 \mu \mathrm{g} / \mathrm{mL}$, compared to its MIC of 32 $\mu \mathrm{g} / \mathrm{mL}$. A combination treatment results in biofilm eradication with $16 \mu \mathrm{g} / \mathrm{mL}$ BPEI and 8 $\mu \mathrm{g} / \mathrm{mL}$ piperacillin. As with the planktonic checkerboard assays, this data was collected without a $\beta$-lactamase inhibitor. The mechanism of action for disrupting the biofilm relies on the ability of cationic 600 Da BPEI to interact with anionic targets. Instead of binding with LPS in the planktonic cells, the biofilm targets are extracellular DNA, anionic polysaccharide Psl, and anionic polysaccharide alginic acid. ${ }^{46-56}$ The presence of the cationic polysaccharide Pel in $P$. aeruginosa biofilms would repel BPEI, but this effect does not prevent $600 \mathrm{Da} \mathrm{BPEI}$ from disrupting the biofilm matrix; thus, piperacillin can access the underlying cells (Figure 13). The data in Figure 12 also confirms the paradigm that antibiotics effective against planktonic $P$. aeruginosa are nearly inert against biofilms and resistant strains. When 600 Da BPEI binds to EPS, the biofilm disperses because the intermolecular network of exopolymers, protein, and metals ions is disrupted. ${ }^{20}$ As a result, quiescent bacteria are released into solution where they become metabolically active, and thus, the antibiotic can kill the bacteria after additional BPEI molecules reduce LPS barriers to drug influx. 
The antimicrobial properties of cationic compounds are well-documented, including polyethylenimines (PEIs). An important caveat in considering this previous work is that PEIs, whether linear or branched, are available in a wide range of sizes, from 600 to 1000 $000 \mathrm{Da}$. The MW range correlates with the ability to disrupt membranes and cause toxicity toward eukaryotic cells. Fortunately, $600 \mathrm{Da}$ BPEI has low toxicity, is nonmutagenic, and has high biocompatibility, ${ }^{58}$ and the low likelihood of causing red blood cell hemolysis has been demonstrated. ${ }^{59}$ Khalil et al. reported the synergy of PEI with various antibiotics. ${ }^{60}$ However, this work used $10 \mathrm{kDa}$ PEI, which has a high toxicity, at a concentration of 250 $\mu \mathrm{g} / \mathrm{mL}$, which is $25 \mu \mathrm{M}$ rather than the reported concentration of $250 \mathrm{nM}$. Nevertheless, the potentiation of antibiotics varied across different classes, with modest potentiation of $\beta$ lactams and no potentiation of erythromycin. Helander et al. reported that $50 \mathrm{kDa}$ PEI causes catastrophic damage to the outer membrane of Salmonella typhimurium cells at 10 $\mu \mathrm{g} / \mathrm{mL} .{ }^{61}$ This work was followed by a study of increased NPN uptake in Escherichia coli, $S$. typhimurium, and $P$. aeruginosa from citrate that chelates metal ions and the restoration of the diffusion barrier by excess $\mathrm{Mg}^{2+}$ ions. ${ }^{62}$ Hancock and co-workers published an elegant summary of ways to overcome resistance mechanisms. ${ }^{37}$ The strategy described by Hancock and Wong involves disrupting $\mathrm{Mg}^{2+}$ chelation by LPS in the outer envelope ${ }^{63}$ Cationic oligo-acyl-lysyls have 3 primary amines that potentiate rifampicin against $K$. pneumoniae, but this approach did not lower the MIC of penicillin G. ${ }^{64}$ Recently, Fleeman et al. reported that small polyamines with benzene functional groups were found to be efflux-pump inhibitors, ${ }^{65}$ but using the efflux deficient mutant $\mathrm{Pa} \Delta 3$, our data show that $600 \mathrm{Da}$ BPEI does not inhibit efflux pumps but instead functions by increasing antibiotic permeation. Synthetic diamines are reported to have antibacterial and antibiofilm properties against $P$. aeruginosa PAO1 via membrane depolarization and disruption. ${ }^{66}$ Kwon and Lu found that spermine exhibited synergy with antibiotics against Staphylococcus aureus and $P$. aeruginosa PAO1. ${ }^{67}$ Although spermine increased the MICs of cationic peptides, aminoglycosides, and quinolone antibiotics, there was a decrease in the MICs of $\beta$-lactams, chloramphenicol, and polymyxin $\mathrm{B}$ after the addition of $1 \mathrm{mM}$ spermine. In contrast, $600 \mathrm{Da}$ BPEI produces superior results where the piperacillin MIC is lowered to $1 \mu \mathrm{g} / \mathrm{mL}$ with only $13.5 \mu \mathrm{M}$ (8 $\mu \mathrm{g} / \mathrm{mL}) 600$ Da BPEI.

Generally regarded as safe and effective, $\beta$-lactams are the \#1 option for treating infections. $\beta$-Lactams are favored as antibacterial agents. ${ }^{68-71}$ Clinicians prescribed 118 million courses of $\beta$-lactam antibiotics in 2011. ${ }^{72}$ The recommended treatment of pediatric infections is amoxicillin. ${ }^{73,74}$ These options disappear for infections resistant to $\beta$-lactams, which arise from the presence of $\beta$-lactamase enzymes that function via hydrolytic cleavage of the lactam ring. Combinations of $\beta$-lactams with $\beta$-lactamase inhibitors (amoxicillin + clavulanic acid or piperacillin + tazobactam) are used against Gram-negative bacteria. ${ }^{75,76}$ Here, 600 Da BPEI targets LPS-mediated resistance in MDR-PA and restores piperacillin efficacy without the need for $\beta$-lactamase inhibitors. Additionally, $600 \mathrm{Da}$ BPEI will be attracted to anionic components of the bacterial biofilm, resulting in disruption of the extracellular matrix that dissolves the biofilms to enable antibiofilm activity of piperacillin. Thus, 600 Da BPEI may improve patient care outcomes by restoring potency to existing antibiotics with a single potentiator. An advantage of $600 \mathrm{Da} \mathrm{BPEI}$ is that it does not need to cross the membrane itself to be effective. By targeting the anionic inner-core and outer-core 
polysaccharides ${ }^{35,77}$ and biofilm EPS, $600 \mathrm{Da}$ BPEI creates new avenues of access for antibiotics to reach their targets. Thus, BPEI does not have to traverse the membrane for potentiation. This contrasts with other cationic antimicrobial agents, such as cationic peptides, aminoglycosides, and polymyxins, whose hydrophobic properties are required for membrane disruption. The delicate balance between potentiation at low concentration and antimicrobial properties at high concentration are possible because we are using $600 \mathrm{Da}$ BPEI, in contrast to PEIs over $10 \mathrm{kDa}$ that cause widespread membrane disruption and do not have potentiation properties. ${ }^{17}$ Nevertheless, the data support the premise that $600 \mathrm{Da}$ BPEI increases the influx of fluorescence dyes (Figure 7A) and does not block efflux pumps (Figure 7B). There is a strong correlation between increased dye uptake and $600 \mathrm{Da}$ BPEI concentration. The presence of efflux pump processes in the WT strain prevents a clear delineation of the trends. However, using the data for the efflux-pump deficient mutant (Figure 7B), the trend is clear. $64 \mu \mathrm{g} / \mathrm{mL} 600 \mathrm{Da}$ BPEI (circles in Figure 7B) causes an increase in $\mathrm{H} 33342$ intensity. However, this amount has a negligible effect on cell viability, as determined from the resazurin assay (Figure S6). This is in stark contrast to polymyxin B that is lethal to the cells at $64 \mu \mathrm{g} / \mathrm{mL}$ (Figure S6). Thus, we believe that it is appropriate to discuss the $600 \mathrm{Da}$ BPEI MOA, reducing drug diffusion barriers from LPS, as it is different than the well-established membrane disruption MOA of polymyxin B. This interpretation is also supported by the NPN assay data in Figure 10.

\section{CONCLUSION}

We envision $600 \mathrm{Da}$ BPEI as a topical agent applied to acute and chronic wounds. Instead of taking 3-6 weeks to heal, chronic wounds persist for 3-6 months, ${ }^{10}$ in large part due to infections with bacteria exhibiting antimicrobial resistance (AMR) and their associated biofilms. ${ }^{4,5}$ Each year, chronic wounds arise from the hundreds of millions of acute skin and soft-tissue infections (SSTIs) ${ }^{7}$ because anti-infective therapeutics work against many but not all SSTIs. The estimated 4.5 million chronic wound infections ${ }^{78-81}$ increase the risk of recurrent infection and tissue necrosis 82,83 and are a major problem in healthcare and community settings. ${ }^{2,82,83}$ Because 600 Da BPEI + antibiotic combinations can kill susceptible and resistant bacteria in their biofilm and planktonic environments, this strategy can reduce the bacterial burden in wound infections and speed healing before acute SSTIs become chronic, complicated infections. ${ }^{7}$ Topical use reduces problems of matching pharmacokinetics (PK) and pharmacodynamics (PD) with those of antibiotics. There is a strong likelihood of developing a topical agent for wound treatment because the watersoluble hydrophilic properties of $600 \mathrm{Da}$ BPEI enable easy drug delivery to directly attack AMR and biofilms in the wound environment. There are minimal protein binding effects that would prevent activity in the wound environment, demonstrated with antibiotic potentiation assays using fetal bovine serum (FBS). ${ }^{17}$ Growth media were prepared with 50\% FBS, which did not change the oxacillin MIC. ${ }^{17}$ Likewise, when 600 Da BPEI was subsequently added, serum proteins did not hinder potentiation. This is not surprising as $600 \mathrm{Da} \mathrm{BPEI}$ is very hydrophilic and would only bind with protein anionic groups that are accessible and not chelated with a metal or other protein residues. We reported minimal in vitro cytotoxicity ${ }^{17}$ in studies that were serum-free in order to obtain a more accurate evaluation of toxicity without serum proteins preventing contact with the eukaryotic cells. The low cytotoxicity 
differentiates 600 Da BPEI from polymyxins. ${ }^{38}$ In vivo toxicity issues are paramount, which will be the subject of future research investigations.

\section{METHODS}

Materials.

In this study, Pseudomonas aeruginosa bacteria were purchased from the American Type Culture Collection (ATCC BAA-47 and 27853). Additional MDR-PA strains were obtained from clinical isolates from the University of Oklahoma Health Sciences Center using appropriate IRB protocols and procedures. Wild-type $P$. aeruginosa PAO1 and its efflux pump deficient mutant, $\mathrm{Pa} \Delta 3$, were kindly provided by Prof. Helen Zgurskaya, University of Oklahoma. Chemicals were purchased from Sigma-Aldrich (DMSO, growth media, and electron microscopy fixatives). Antibiotics were purchased from Gold Biotechnology. 600 Da BPEI was purchased from Polysciences, Inc. MBEC Biofilm Inoculator with 96-well base plates was purchased from Innovotech, Inc.

\section{Checkerboard Assays and Growth Curves.}

Checkerboard assays followed the methods of Lam et al. ${ }^{20}$ to determine the synergistic effect between $600 \mathrm{Da}$ BPEI and antibiotics against the $P$. aeruginosa strains growing in cation-adjusted Mueller-Hinton broth (CAMHB). Bacterial growth curves were obtained using CAMHB media augmented with various amounts of $600 \mathrm{Da}$ BPEI and/or piperacillin inoculated with $P$. aeruginosa BAA-47 cells from an overnight culture $\left(5 \times 10^{5} \mathrm{CFU} / \mathrm{mL}\right)$. Cells were grown at $35^{\circ} \mathrm{C}$ with shaking. The $\mathrm{OD}_{600}$ (optical density at $600 \mathrm{~nm}$ ) was monitored and recorded for each sample over $24 \mathrm{~h}$. Each checkerboard trial was done in triplicate using sterile Greiner CellStar flat bottom polystyrene plates, catalog \#655180. Each growth curve was done in duplicate.

\section{MBEC Assay.}

The MBEC assay is adapted from previous literature reports. ${ }^{22,57}$

\section{Inoculation and Biofilm Formation.}

A subculture of $P$. aeruginosa BAA-47 was grown from the cryogenic stock on an agar plate overnight at $35^{\circ} \mathrm{C}$. The MBEC plate was inoculated with $150 \mu \mathrm{L}$ of CAMHB/well plus $1 \mu \mathrm{L}$ of a stock culture made from 1 colony/mL $P$. aeruginosa BAA-47 in CAMHB $\left(\sim 5 \times 10^{5}\right.$ $\mathrm{CFU} / \mathrm{mL}$ ). The MBEC inoculator plate was sealed with Parafilm and incubated for $24 \mathrm{~h}$ at $35^{\circ} \mathrm{C}$ with $100 \mathrm{rpm}$ shaking to facilitate biofilm formation on the prongs. Following biofilm formation, the lid of the MBEC inoculator was removed and placed in a rinse plate containing $200 \mu \mathrm{L}$ of sterile PBS for $10 \mathrm{~s}$.

\section{Antimicrobial Challenge.}

A challenge plate was made in a new presterilized 96-well plate in a checkerboard-assay pattern to test the synergistic activity of $600 \mathrm{Da} \mathrm{BPEI}+$ antibiotic combinations.

Antimicrobial solutions were serial-diluted and added to the 96-well plate, which contained $200 \mu \mathrm{L}$ of CAMHB per well. After the rinsing step, the preformed biofilm prong lid was 
immediately transferred into the prepared antimicrobial challenge plate and incubated at 35 ${ }^{\circ} \mathrm{C}$ for $20-24 \mathrm{~h}$.

\section{Recovery and Quantitative MBEC.}

After the challenge period, the MBEC inoculator lid was washed and transferred into a recovery plate containing $200 \mu \mathrm{L}$ of CAMHB per well, sonicated on high (Branson B-220, frequency of $40 \mathrm{kHz}$ ) for $30 \mathrm{~min}$ to dislodge the biofilm, and then incubated at $35^{\circ} \mathrm{C}$ for 20 $24 \mathrm{~h}$ to allow the surviving bacterial cells to grow. After incubation, the $\mathrm{OD}_{600}$ of the recovery plate was measured using a Tecan Infinite M20 plate reader to determine the MBEC of the antimicrobial compounds tested. A change in $\mathrm{OD}_{600}$ greater than 0.05 indicated growth. Likewise, the $\mathrm{OD}_{600}$ for the base of the challenge plate was measured to determine the MICs of the antimicrobial compounds. The fractional inhibitory concentration index (FICI) calculated on the basis of the established equation ${ }^{23}$ was used to determine synergy (FICI $\leq 0.5)$, additivity $(0.5<$ FICI $<1)$, and no synergy $($ FICI $\geq 1)$.

\section{Scanning Electron Microscopy.}

P. aeruginosa BAA-47 cells were inoculated from an overnight culture $\left(5 \times 10^{5} \mathrm{CFU} / \mathrm{mL}\right)$ and grown at $35^{\circ} \mathrm{C}$ with shaking. The bacteria were grown in four separate sublethal treatments: 600 Da BPEI $(4 \mu \mathrm{g} / \mathrm{mL})$, piperacillin $(1 \mu \mathrm{g} / \mathrm{mL})$, combination $(4 \mu \mathrm{g} / \mathrm{mL} 600 \mathrm{Da}$ $\mathrm{BPEI}+1 \mu \mathrm{g} / \mathrm{mL}$ piperacillin), and untreated control. Growth was stopped at late-lag phase. Samples were collected by centrifugation and fixed with Karnovsky fixative (2\% glutaraldehyde and $2 \%$ paraformaldehyde in $0.1 \mathrm{M}$ cacodylate buffer) for $30 \mathrm{~min}$. The cells were then fixed with $1 \% \mathrm{OsO}_{4}$ for $30 \mathrm{~min}$ in the dark. The cells were washed with water three times. A couple drops of each sample were placed on clean, poly-L-lysine coated coverslips and air-dried for $30 \mathrm{~min}$. The samples were dehydrated by going through a series of ethanol solutions (20\%, 35\%, 50\%, 70\%, and 95\%), spending $15 \mathrm{~min}$ in each solution. Afterward, the samples were dried with hexamethyldisilazane (HMDS). They were then mounted on aluminum stubs with carbon tape and sputter coated with AuPd. A Zeiss NEON SEM was used to image the samples at $5 \mathrm{kV}$ accelerating voltage.

\section{Isothermal Titration Calorimetry (ITC).}

An isothermal titration calorimeter (MicroCal PEAQ-ITC, Malvern Inc., Malvern, U.K.) was used to assess $P$. aeruginosa lipopolysaccharide (LPS) binding with 600 Da BPEI. Solutions of BPEI $(0.64 \mathrm{mg} / \mathrm{mL})$ and L8643 P. aeruginosa LPS $(5 \mathrm{mg} / \mathrm{mL})$ were prepared in $50 \mathrm{mM}$ Tris- $\mathrm{HCl}$ (pH 7) buffer at $25^{\circ} \mathrm{C}$. Titrations were carried out at $25^{\circ} \mathrm{C}$ using injections of $2 \mu \mathrm{L}$ that lasted $4 \mathrm{~s}$ and were separated by $150 \mathrm{~s}$ time intervals. For each experimental setup, controls were performed in which the titrant was injected into pure buffer, buffer was injected into the cell, and buffer was injected into pure buffer. The experiment was done in duplicate.

\section{H33342 Bisbenzimide and NPN Accumulation Assays.}

An overnight culture of $P$. aeruginosa BAA-47 was used to inoculate fresh CAMHB media for another $5 \mathrm{~h}$ at $35^{\circ} \mathrm{C}$ with shaking. Bacterial cells were collected by centrifugation at $6000 \mathrm{rpm}$ for $40 \mathrm{~min}$ and resuspended in PBS. The $\mathrm{OD}_{600}$ of the cell suspension was 
adjusted to $\sim 1.0$ and kept at room temperature during the experiment. Aliquots (180 $\mu \mathrm{L} /$ well) of the cell suspension were transferred to a 96-well flat-bottom black plate in the format of column 1, PBS blank; column 2, untreated control cells BAA-47; column 3, cells BAA-47 + BPEI (sublethal concentration). Five technical replicates of each group were conducted. Fluorescent probes ${ }^{40-42}$ Hoechst 33342 bisbenzimide (H33342) or $1-N$ phenylnaphthylamine (NPN) were added $(20 \mu \mathrm{L})$ to each well with a final concentration of 5 $\mu \mathrm{M}$. Fluorescence was read immediately after the addition of H33342 or NPN by a Tecan Infinite M20 plate reader with the excitation and emission filters of 355 and $460 \mathrm{~nm}$ for $\mathrm{H} 33342$ or 350 and $420 \mathrm{~nm}$ for NPN, respectively. Fluorescence data were normalized to the emission before cells were added in the PBS control, and they were plotted against time to show the cellular uptake of H33342 or NPN over 10 min. Fluorescence emission values obtained from the control experiments of dye +600 Da BPEI were the same as those of dye only.

\section{Supplementary Material}

Refer to Web version on PubMed Central for supplementary material.

\section{ACKNOWLEDGMENTS}

Funding was provided by the National Institutes of Health (C.V.R., R03AI142420-01), the Oklahoma Center of Advancement of Science and Technology (C.V.R., HR16-084-3), and The University of Oklahoma. This work was possible due to the kindness and contributions of Prof. Helen Zgurskaya, including helpful discussions and providing the PAO1 and $\mathrm{Pa} \triangle 3$ bacteria used in this work. We want to thank Dr. Phil Bourne and acknowledge the use of the Protein Production Core (PPC) at the University of Oklahoma, Norman. PPC is supported by an Institutional Development Award (IDeA) from the National Institute of General Medical Sciences of the National Institutes of Health under grant number P20GM103640. We would also like to acknowledge the valuable insight and suggestions provided by Prof. Robert Brennan, University of Central Oklahoma.

\section{ABBREVIATIONS}

MDR

BPEI

EPS

SEM

DMSO

PBS

MIC

MBEC

AuPd

PIP

PmB multidrug-resistant

branched polyethylenimine

extracellular polymeric substance

scanning electron microscopy

dimethyl sulfoxide

phosphate-buffered saline

minimum inhibitory concentration

minimum biofilm eradication concentration

gold palladium

piperacillin

polymyxin B 


$\begin{array}{ll}\text { HMDS } & \text { hexamethyldisilazane } \\ \text { OD }_{600} & \text { optical density at } 600 \mathrm{~nm} \\ \text { CAMHB } & \text { cation-adjusted Muller-Hinton broth } \\ \text { TSB } & \text { tryptic soy broth } \\ \text { Da } & \text { Dalton }\end{array}$

\section{口 REFERENCES}

(1). Lyczak JB, Cannon CL, and Pier GB (2000) Establishment of Pseudomonas aeruginosa infection: lessons from a versatile opportunist. Microbes Infect. 2 (9), 1051-1060. [PubMed: 10967285]

(2). Frykberg RG, and Banks J (2015) Challenges in the Treatment of Chronic Wounds. Adv. Wound Care 4 (9), 560-582.

(3). Branski LK, Al-Mousawi A, Rivero H, Jeschke MG, Sanford AP, and Herndon DN (2009) Emerging infections in burns. Surg Infect 10 (5), 389-397.

(4). Davies D (2003) Understanding biofilm resistance to antibacterial agents. Nat. Rev. Drug Discovery 2 (2), 114-122. [PubMed: 12563302]

(5). Costerton JW, Stewart PS, and Greenberg EP (1999) Bacterial biofilms: a common cause of persistent infections. Science 284 (5418), 1318-1322. [PubMed: 10334980]

(6). Drenkard E, and Ausubel FM (2002) Pseudomonas biofilm formation and antibiotic resistance are linked to phenotypic variation. Nature 416 (6882), 740-743. [PubMed: 11961556]

(7). Lim HW, Collins SAB, Resneck JS Jr., Bolognia JL, Hodge JA, Rohrer TA, Van Beek MJ, Margolis DJ, Sober AJ, Weinstock MA, Nerenz DR, Smith Begolka W, and Moyano JV (2017) The burden of skin disease in the United States. J. Am. Acad. Dermatol 76 (5), 958-972.e2. [PubMed: 28259441]

(8). Centers for Disease Control and Prevention (2017) National Diabetes Statistics Report, Centers for Disease Control and Prevention, US Department of Health and Human Services, Atlanta, GA.

(9). Lavery LA, Armstrong DG, Murdoch DP, Peters EJ, and Lipsky BA (2007) Validation of the Infectious Diseases Society of America's diabetic foot infection classification system. Clin. Infect. Dis 44 (4), 562-565. [PubMed: 17243061]

(10). Swanson T, Wolcott RD, Wallis H, and Woodmansey EJ (2017) Understanding biofilm in practice: a global survey of health professionals. J. Wound Care 26 (8), 426-440. [PubMed: 28795881]

(11). Fazli M, Bjarnsholt T, Kirketerp-Moller K, Jorgensen B, Andersen AS, Krogfelt KA, Givskov M, and Tolker-Nielsen T (2009) Nonrandom distribution of Pseudomonas aeruginosa and Staphylococcus aureus in chronic wounds. J. Clin Microbiol 47 (12), 4084-4089. [PubMed: 19812273]

(12). Malic S, Hill KE, Hayes A, Percival SL, Thomas DW, and Williams DW (2009) Detection and identification of specific bacteria in wound biofilms using peptide nucleic acid fluorescent in situ hybridization (PNA FISH). Microbiology 155 (8), 2603-2611. [PubMed: 19477903]

(13). Gjodsbol K, Christensen JJ, Karlsmark T, Jorgensen B, Klein BM, and Krogfelt KA (2006) Multiple bacterial species reside in chronic wounds: a longitudinal study. Int. Wound J 3 (3), 225-231. [PubMed: 16984578]

(14). Stover CK, Pham XQ, Erwin AL, Mizoguchi SD, Warrener P, Hickey MJ, Brinkman FS, Hufnagle WO, Kowalik DJ, Lagrou M, Garber RL, Goltry L, Tolentino E, Westbrock-Wadman S, Yuan Y, Brody LL, Coulter SN, Folger KR, Kas A, Larbig K, Lim R, Smith K, Spencer D, Wong GK, Wu Z, Paulsen IT, Reizer J, Saier MH, Hancock RE, Lory S, and Olson MV (2000) Complete genome sequence of Pseudomonas aeruginosa PAO1, an opportunistic pathogen. Nature 406 (6799), 959-964. [PubMed: 10984043]

(15). Dongari-Bagtzoglou A (2008) Pathogenesis of mucosal biofilm infections: challenges and progress. Expert Rev. Anti-Infect. Ther 6 (2), 201-208. [PubMed: 18380602] 
(16). Vermote A, and Van Calenbergh S (2017) Small-Molecule Potentiators for Conventional Antibiotics against Staphylococcus aureus. ACS Infect. Dis 3 (11), 780-796. [PubMed: 28889735]

(17). Foxley MA, Wright SN, Lam AK, Friedline AW, Strange SJ, Xiao MT, Moen EL, and Rice CV (2017) Targeting Wall Teichoic Acid in Situ with Branched Polyethylenimine Potentiates betaLactam Efficacy against MRSA. ACS Med. Chem. Lett 8 (10), 1083-1088. [PubMed: 29057055]

(18). Foxley MA, Friedline AW, Jensen JM, Nimmo SL, Scull EM, King JB, Strange S, Xiao MT, Smith BE, Thomas KJ III, Glatzhofer DT, Cichewicz RH, and Rice CV (2016) Efficacy of ampicillin against methicillin-resistant Staphylococcus aureus restored through synergy with branched poly(ethylenimine). J. Antibiot 69 (12), 871-878. [PubMed: 27189119]

(19). Hill MA, Lam AK, Reed P, Harney MC, Wilson BA, Moen EL, Wright SN, Pinho MG, and Rice CV (2019) BPEI-Induced Delocalization of PBP4 Potentiates beta-Lactams against MRSA. Biochemistry 58 (36), 3813-3822. [PubMed: 31429286]

(20). Lam AK, Wouters CL, Moen EL, Pusavat J, and Rice CV (2019) Antibiofilm Synergy of betaLactams and Branched Polyethylenimine against Methicillin-Resistant Staphylococcus epidermidis. Biomacromolecules 20 (10), 3778-3785. [PubMed: 31430130]

(21). Nguyen ST, Ding X, Butler MM, Tashjian TF, Peet NP, and Bowlin TL (2011) Preparation and antibacterial evaluation of decarboxylated fluoroquinolones. Bioorg. Med. Chem. Lett 21 (19), 5961-5963. [PubMed: 21865042]

(22). Lam AK, Hill MA, Moen EL, Pusavat J, Wouters CL, and Rice CV (2018) Cationic Branched Polyethylenimine (BPEI) Disables Antibiotic Resistance in Methicillin-Resistant Staphylococcus epidermidis (MRSE). ChemMedChem 13 (20), 2240-2248. [PubMed: 30193012]

(23). USCAST (2019) Breakpoint tables for interpretation of MICs and zone diameters, ver. 3.0, http:// www.uscast.org.

(24). Kojima S, and Nikaido H (2013) Permeation rates of penicillins indicate that Escherichia coli porins function principally as nonspecific channels. Proc. Natl. Acad. Sci. U. S. A 110 (28), E2629-2634. [PubMed: 23798411]

(25). Zgurskaya HI, Lopez CA, and Gnanakaran S (2015) Permeability Barrier of Gram-Negative Cell Envelopes and Approaches To Bypass It. ACS Infect. Dis 1 (11), 512-522. [PubMed: 26925460]

(26). Nascimento A Jr., Pontes FJ, Lins RD, and Soares TA (2014) Hydration, ionic valence and crosslinking propensities of cations determine the stability of lipopolysaccharide (LPS) membranes. Chem. Commun 50 (2), 231-233.

(27). Srimal S, Surolia N, Balasubramanian S, and Surolia A (1996) Titration calorimetric studies to elucidate the specificity of the interactions of polymyxin B with lipopolysaccharides and lipid A. Biochem. J 315 (2), 679-686. [PubMed: 8615847]

(28). Jo S, Wu EL, Stuhlsatz D, Klauda JB, MacKerell AD, Widmalm G, and Im W (2015) Lipopolysaccharide Membrane Building and Simulation. In Glycoinformatics (Lütteke T, and Frank M, Eds.) pp 391-406, Springer New York, New York, NY, DOI: 10.1007/978-1-4939-2343-4_24.

(29). Dias RP, Lin L, Soares TA, and Alexov E (2014) Modeling the electrostatic potential of asymmetric lipopolysaccharide membranes: the MEMPOT algorithm implemented in DelPhi. J. Comput. Chem 35 (19), 1418-1429. [PubMed: 24799021]

(30). Knirel YA, Bystrova OV, Kocharova NA, Zahringer U, and Pier GB (2006) Conserved and variable structural features in the lipopolysaccharide of Pseudomonas aeruginosa. J. Endotoxin Res 12 (6), 324-336. [PubMed: 17254386]

(31). Barkleit A, Moll H, and Bernhard G (2008) Interaction of uranium(VI) with lipopolysaccharide. Dalton Trans 21, 2879-2886.

(32). Krishnamoorthy G, Leus IV, Weeks JW, Wolloscheck D, Rybenkov VV, and Zgurskaya HI (2017) Synergy between Active Efflux and Outer Membrane Diffusion Defines Rules of Antibiotic Permeation into Gram-Negative Bacteria. mBio 8, e01172-17. [PubMed: 29089426]

(33). Rampersad SN (2012) Multiple applications of Alamar Blue as an indicator of metabolic function and cellular health in cell viability bioassays. Sensors 12 (9), 12347-12360. [PubMed: 23112716] 
(34). Westfall DA, Krishnamoorthy G, Wolloscheck D, Sarkar R, Zgurskaya HI, and Rybenkov VV (2017) Bifurcation kinetics of drug uptake by Gram-negative bacteria. PLoS One 12 (9), No. e0184671. [PubMed: 28926596]

(35). Clifton LA, Ciesielski F, Skoda MW, Paracini N, Holt SA, and Lakey JH (2016) The Effect of Lipopolysaccharide Core Oligosaccharide Size on the Electrostatic Binding of Antimicrobial Proteins to Models of the Gram Negative Bacterial Outer Membrane. Langmuir 32 (14), 34853494. [PubMed: 27003358]

(36). Hancock RE, Farmer SW, Li ZS, and Poole K (1991) Interaction of aminoglycosides with the outer membranes and purified lipopolysaccharide and OmpF porin of Escherichia coli. Antimicrob. Agents Chemother 35 (7), 1309-1314. [PubMed: 1656859]

(37). Gill EE, Franco OL, and Hancock RE (2015) Antibiotic adjuvants: diverse strategies for controlling drug-resistant pathogens. Chem. Biol. Drug Des 85 (1), 56-78. [PubMed: 25393203]

(38). Trimble MJ, Mlynarcik P, Kolar M, and Hancock RE (2016) Polymyxin: Alternative Mechanisms of Action and Resistance. Cold Spring Harbor Perspect. Med 6 (10), a025288.

(39). Humphries RM, Ambler J, Mitchell SL, Castanheira M, Dingle T, Hindler JA, Koeth L, Sei K, Development CM, et al. (2018) Standardization Working Group of the Subcommittee on Antimicrobial Susceptibility, T., CLSI Methods Development and Standardization Working Group Best Practices for Evaluation of Antimicrobial Susceptibility Tests. J. Clin. Microbiol 56 (4), e01934-17. [PubMed: 29367292]

(40). Helander IM, Alakomi HL, Latva-Kala K, and Koski P (1997) Polyethyleneimine is an effective permeabilizer of gram-negative bacteria. Microbiology 143 (10), 3193-3199. [PubMed: 9353921]

(41). Loh B, Grant C, and Hancock RE (1984) Use of the fluorescent probe 1-N-phenylnaphthylamine to study the interactions of aminoglycoside antibiotics with the outer membrane of Pseudomonas aeruginosa. Antimicrob. Agents Chemother 26 (4), 546-551. [PubMed: 6440475]

(42). Hancock RE, and Wong PG (1984) Compounds which increase the permeability of the Pseudomonas aeruginosa outer membrane. Antimicrob. Agents Chemother 26 (1), 48-52. [PubMed: 6433788]

(43). Lutkenhaus J, Pichoff S, and Du S (2012) Bacterial cytokinesis: From Z ring to divisome. Cytoskeleton 69 (10), 778-790. [PubMed: 22888013]

(44). de Boer PA (2010) Advances in understanding E. coli cell fission. Curr. Opin. Microbiol 13 (6), 730-737. [PubMed: 20943430]

(45). Stevens DL, Bisno AL, Chambers HF, Dellinger EP, Goldstein EJ, Gorbach SL, Hirschmann JV, Kaplan SL, Montoya JG, and Wade JC (2014) Practice guidelines for the diagnosis and management of skin and soft tissue infections: 2014 update by the infectious diseases society of America. Clin. Infect. Dis 59 (2), 147-159. [PubMed: 24947530]

(46). Jennings LK, Storek KM, Ledvina HE, Coulon C, Marmont LS, Sadovskaya I, Secor PR, Tseng BS, Scian M, Filloux A, Wozniak DJ, Howell PL, and Parsek MR (2015) Pel is a cationic exopolysaccharide that cross-links extracellular DNA in the Pseudomonas aeruginosa biofilm matrix. Proc. Natl. Acad. Sci. U. S. A 112 (36), 11353-8. [PubMed: 26311845]

(47). Holland LM, Conlon B, and O'Gara JP (2011) Mutation of tagO reveals an essential role for wall teichoic acids in Staphylococcus epidermidis biofilm development. Microbiology 157 (2), 408 418. [PubMed: 21051486]

(48). Joo HS, and Otto M (2015) Mechanisms of resistance to antimicrobial peptides in staphylococci. Biochim. Biophys. Acta, Biomembr 1848 (11), 3055-3061.

(49). Krismer B, Weidenmaier C, Zipperer A, and Peschel A (2017) The commensal lifestyle of Staphylococcus aureus and its interactions with the nasal microbiota. Nat. Rev. Microbiol 15 (11), 675-687. [PubMed: 29021598]

(50). Sadovskaya I, Vinogradov E, Li J, and Jabbouri S (2004) Structural elucidation of the extracellular and cell-wall teichoic acids of Staphylococcus epidermidis RP62A, a reference biofilm-positive strain. Carbohydr. Res 339 (8), 1467-73. [PubMed: 15178389]

(51). Vinogradov E, Sadovskaya I, Li J, and Jabbouri S (2006) Structural elucidation of the extracellular and cell-wall teichoic acids of Staphylococcus aureus MN8m, a biofilm forming strain. Carbohydr. Res 341 (6), 738-43. [PubMed: 16458275] 
(52). Wagstaff JL, Sadovskaya I, Vinogradov E, Jabbouri S, and Howard MJ (2008) Poly-Nacetylglucosamine and poly(glycerol phosphate) teichoic acid identification from staphylococcal biofilm extracts using excitation sculptured TOCSY NMR. Mol. BioSyst 4 (2), 170-4. [PubMed: 18213410]

(53). Arciola CR, Campoccia D, Speziale P, Montanaro L, and Costerton JW (2012) Biofilm formation in Staphylococcus implant infections. A review of molecular mechanisms and implications for biofilm-resistant materials. Biomaterials 33 (26), 5967-82. [PubMed: 22695065]

(54). Bucher T, Oppenheimer-Shaanan Y, Savidor A, Bloom-Ackermann Z, and Kolodkin-Gal I (2015) Disturbance of the bacterial cell wall specifically interferes with biofilm formation. Environ. Microbiol. Rep 7 (6), 990-1004. [PubMed: 26472159]

(55). Laverty G, Gorman SP, and Gilmore BF (2013) Biomolecular mechanisms of staphylococcal biofilm formation. Future Microbiol. 8 (4), 509-24. [PubMed: 23534362]

(56). O’Neill E, Pozzi C, Houston P, Smyth D, Humphreys H, Robinson DA, and O' Gara JP (2007) Association between methicillin susceptibility and biofilm regulation in Staphylococcus aureus isolates from device-related infections. J. Clin Microbiol 45 (5), 1379-88. [PubMed: 17329452]

(57). Ceri H, Olson ME, Stremick C, Read RR, Morck D, and Buret A (1999) The Calgary Biofilm Device: new technology for rapid determination of antibiotic susceptibilities of bacterial biofilms. J. Clin. Microbiol 37 (6), 1771-6. [PubMed: 10325322]

(58). Wiegand C, Bauer M, Hipler UC, and Fischer D (2013) Poly(ethyleneimines) in dermal applications: biocompatibility and antimicrobial effects. Int. J. Pharm 456 (1), 165-74. [PubMed: 23948135]

(59). Gibney KA, Sovadinova I, Lopez AI, Urban M, Ridgway Z, Caputo GA, and Kuroda K (2012) Poly(ethylene imine)s as antimicrobial agents with selective activity. Macromol. Biosci 12 (9), 1279-89. [PubMed: 22865776]

(60). Khalil H, Chen T, Riffon R, Wang R, and Wang Z (2008) Synergy between polyethylenimine and different families of antibiotics against a resistant clinical isolate of Pseudomonas aeruginosa. Antimicrob. Agents Chemother 52 (5), 1635-41. [PubMed: 18285485]

(61). Helander IM, Latva-Kala K, and Lounatmaa K (1998) Permeabilizing action of polyethyleneimine on Salmonella typhimurium involves disruption of the outer membrane and interactions with lipopolysaccharide. Microbiology 144 (2), 385-390. [PubMed: 9493375]

(62). Helander IM, and Mattila-Sandholm T (2000) Fluorometric assessment of gram-negative bacterial permeabilization. J. Appl. Microbiol 88 (2), 213-9. [PubMed: 10735988]

(63). Hancock REW, and Wong PGW (1984) Compounds Which Increase the Permeability of the Pseudomonas-Aeruginosa Outer-Membrane. Antimicrob. Agents Chemother 26 (1), 48-52. [PubMed: 6433788]

(64). Jammal J, Zaknoon F, Kaneti G, Goldberg K, and Mor A (2015) Sensitization of Gram-negative bacteria to rifampin and OAK combinations. Sci. Rep 5, 9216. [PubMed: 25782773]

(65). Fleeman RM, Debevec G, Antonen K, Adams JL, Santos RG, Welmaker GS, Houghten RA, Giulianotti MA, and Shaw LN (2018) Identification of a Novel Polyamine Scaffold With Potent Efflux Pump Inhibition Activity Toward Multi-Drug Resistant Bacterial Pathogens. Front. Microbiol 9, 1301. [PubMed: 29963035]

(66). Wang B, Pachaiyappan B, Gruber JD, Schmidt MG, Zhang YM, and Woster PM (2016) Antibacterial Diamines Targeting Bacterial Membranes. J. Med. Chem 59 (7), 3140-51. [PubMed: 26964758]

(67). Kwon DH, and Lu CD (2007) Polyamine effects on antibiotic susceptibility in bacteria. Antimicrob. Agents Chemother 51 (6), 2070-7. [PubMed: 17438056]

(68). Mermel LA, Allon M, Bouza E, et al. (2010) Clinical practice guidelines for the diagnosis and management of intravascular catheter-related infection: 2009 update by the Infectious Diseases Society of America (vol 49, pg 1, 2009). Clin. Infect. Dis 50 (7), 1079.

(69). Baddour LM, Wilson WR, Bayer AS, Fowler VG Jr., Tleyjeh IM, Rybak MJ, Barsic B, Lockhart PB, Gewitz MH, Levison ME, Bolger AF, Steckelberg JM, Baltimore RS, Fink AM, O'Gara P, Taubert KA, American Heart Association Committee on Rheumatic Fever, Endocarditis, and Kawasaki Disease of the Council on Cardiovascular Disease in the Young, Council on Clinical Cardiology, Council on Cardiovascular Surgery and Anesthesia, and Stroke Council (2015) 
Infective Endocarditis in Adults: Diagnosis, Antimicrobial Therapy, and Management of Complications: A Scientific Statement for Healthcare Professionals From the American Heart Association. Circulation 132 (15), 1435-1486. [PubMed: 26373316]

(70). McDanel JS, Roghmann MC, Perencevich EN, Ohl ME, Goto M, Livorsi DJ, Jones M, Albertson JP, Nair R, O'Shea AMJ, and Schweizer ML (2017) Comparative Effectiveness of Cefazolin Versus Nafcillin or Oxacillin for Treatment of Methicillin-Susceptible Staphylococcus aureus Infections Complicated by Bacteremia: A Nationwide Cohort Study. Clin. Infect. Dis 65 (1), 100-106. [PubMed: 28379314]

(71). Blumenthal KG, and Shenoy ES (2016) Editorial Commentary: Fortune Favors the Bold: Give a Beta-Lactam! Clin. Infect. Dis 63 (7), 911-3. [PubMed: 27402818]

(72). Hicks LA, Bartoces MG, Roberts RM, Suda KJ, Hunkler RJ, Taylor TH Jr., and Schrag SJ (2015) US outpatient antibiotic prescribing variation according to geography, patient population, and provider specialty in 2011. Clin. Infect. Dis 60 (9), 1308-16. [PubMed: 25747410]

(73). Wald ER, Applegate KE, Bordley C, Darrow DH, Glode MP, Marcy SM, Nelson CE, Rosenfeld RM, Shaikh N, Smith MJ, Williams PV, and Weinberg ST (2013) American Academy of, P., Clinical practice guideline for the diagnosis and management of acute bacterial sinusitis in children aged 1 to 18 years. Pediatrics 132 (1), e262-80. [PubMed: 23796742]

(74). Chow AW, Benninger MS, Brook I, Brozek JL, Goldstein EJ, Hicks LA, Pankey GA, Seleznick M, Volturo G, Wald ER, and File TM Jr. (2012) Infectious Diseases Society of, A., IDSA clinical practice guideline for acute bacterial rhinosinusitis in children and adults. Clin. Infect. Dis 54 (8), e72-e112. [PubMed: 22438350]

(75). Takimoto K, Wang Q, Suzuki D, Katayama M, and Hayashi Y (2017) Clinical efficacy of piperacillin/tazobactam in the treatment of complicated skin and soft tissue infections. Expert Opin. Pharmacother 18 (10), 1027-1034. [PubMed: 28627952]

(76). Fung HB, Chang JY, and Kuczynski S (2003) A practical guide to the treatment of complicated skin and soft tissue infections. Drugs 63 (14), 1459-80. [PubMed: 12834364]

(77). Goldberg JB, Hatano K, and Pier GB (1993) Synthesis of lipopolysaccharide O side chains by Pseudomonas aeruginosa PAO1 requires the enzyme phosphomannomutase. J. Bacteriol 175 (6), 1605-11. [PubMed: 8449870]

(78). Jones RE, Foster DS, and Longaker MT (2018) Management of Chronic Wounds-2018. Jama-J. Am. Med. Assoc 320 (14), 1481-1482.

(79). Sen CK, Gordillo GM, Roy S, Kirsner R, Lambert L, Hunt TK, Gottrup F, Gurtner GC, and Longaker MT (2009) Human skin wounds: a major and snowballing threat to public health and the economy. Wound Repair Regen 17 (6), 763-71. [PubMed: 19903300]

(80). Omar A, Wright JB, Schultz G, Burrell R, and Nadworny P (2017) Microbial Biofilms and Chronic Wounds. Microorganisms 5 (1), 9.

(81). Wolcott R (2015) Disrupting the biofilm matrix improves wound healing outcomes. J. Wound Care 24 (8), 366-71. [PubMed: 26562379]

(82). Schultz G, Bjarnsholt T, James GA, Leaper DJ, McBain AJ, Malone M, Stoodley P, Swanson T, Tachi M, and Wolcott RD (2017) Global Wound Biofilm Expert, P., Consensus guidelines for the identification and treatment of biofilms in chronic nonhealing wounds. Wound Repair Regen 25 (5), 744-757. [PubMed: 28960634]

(83). Zhao G, Usui ML, Lippman SI, James GA, Stewart PS, Fleckman P, and Olerud JE (2013) Biofilms and Inflammation in Chronic Wounds. Adv. Wound Care 2 (7), 389-399. 


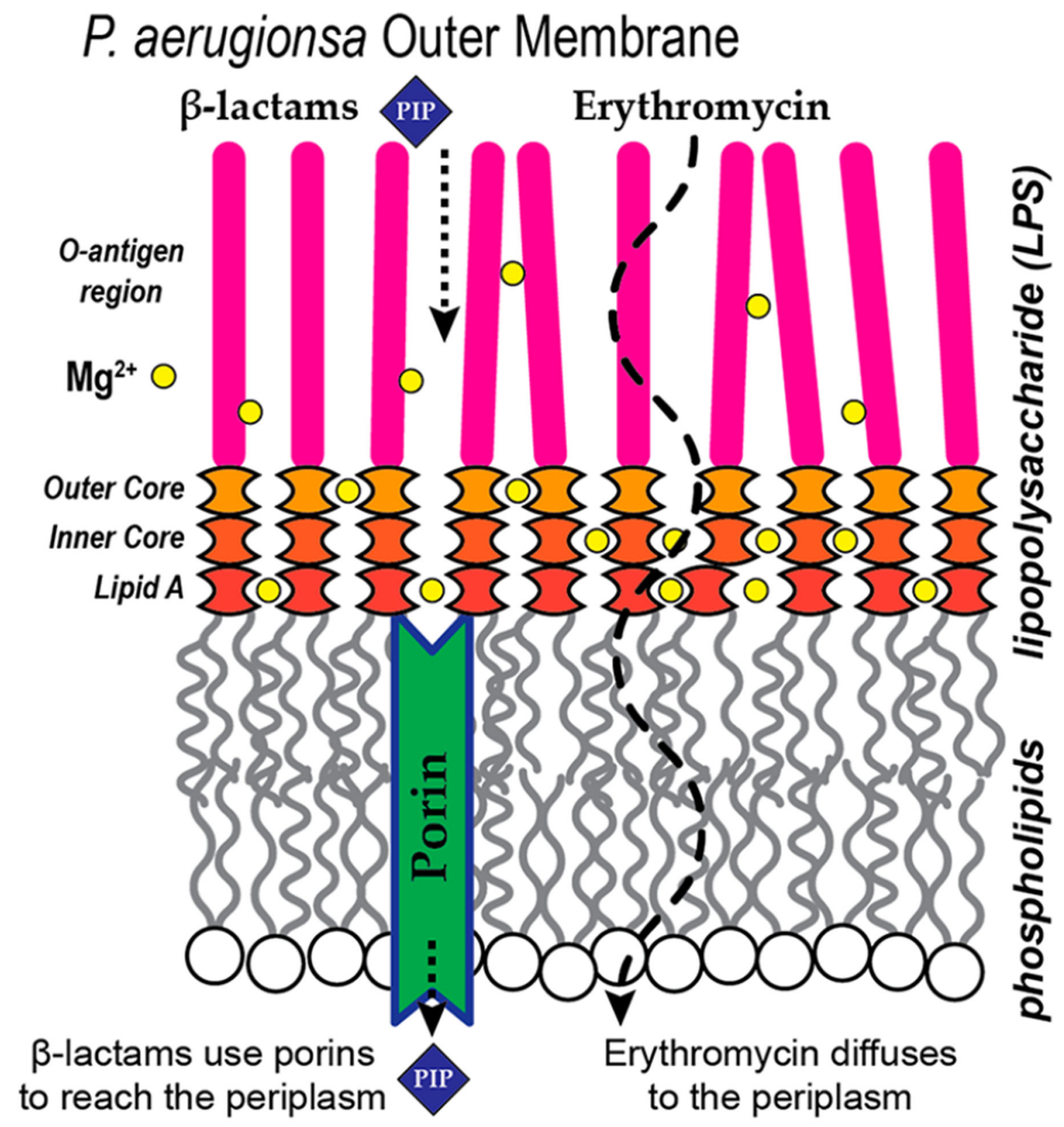

Figure 1.

Illustration of the $P$. aeruginosa outer membrane in which metal ions stabilize the LPS Oantigen, outer-core, inner-core, and lipid A moieties. This presents a barrier to the passive diffusion of a $\beta$-lactam antibiotic to porin transports. Many other compounds, such as erythromycin, rely on passive diffusion to reach the periplasm. 
P. aerugionoa OU1 Growth Assay with 600-Da BPEI and Piperacillin

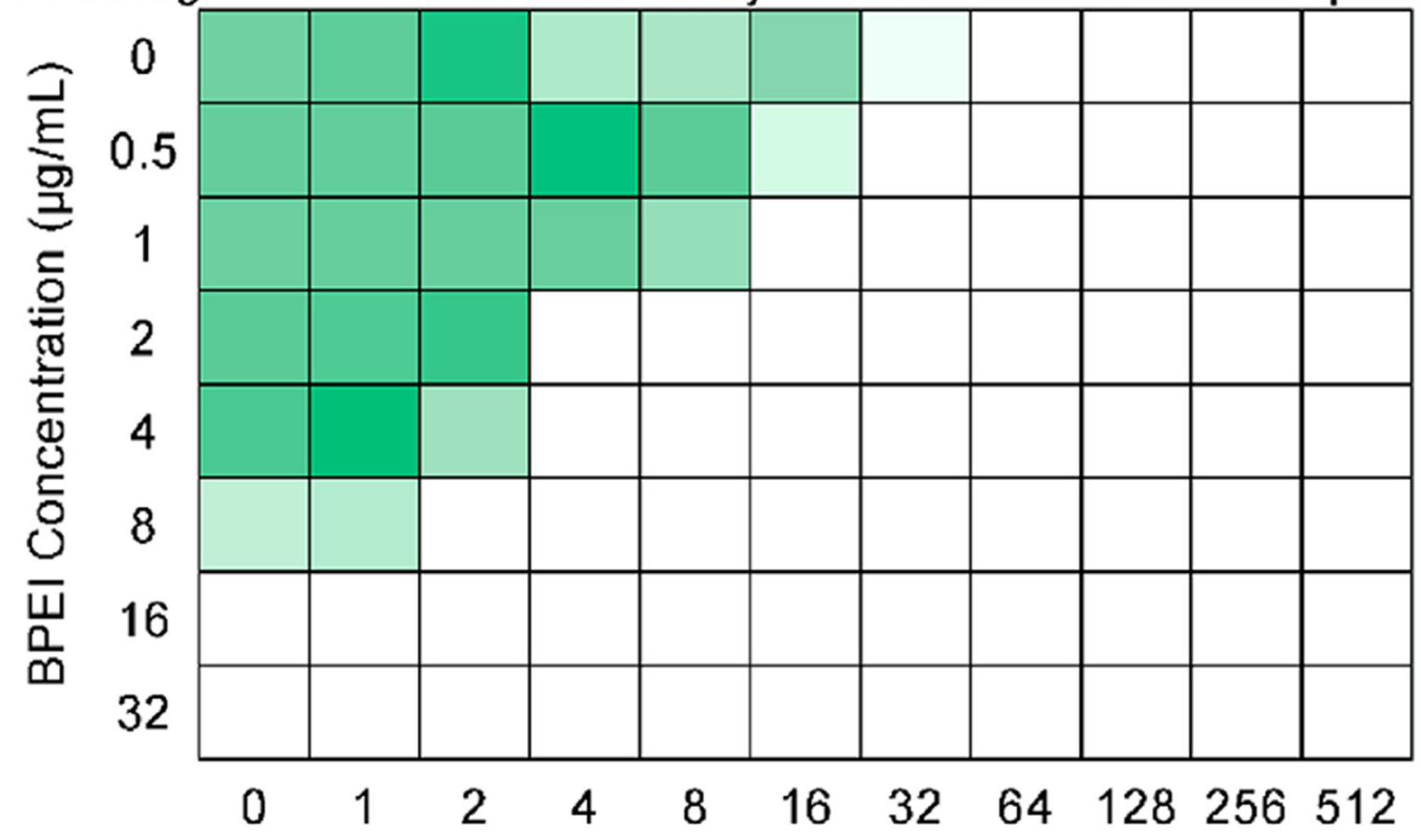

Piperacillin Concentration $(\mu \mathrm{g} / \mathrm{mL})$

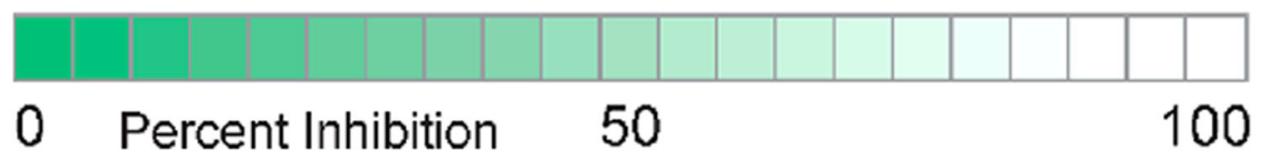

Figure 2.

Checkerboard assay data demonstrating that sublethal amounts of 600 Da BPEI lower the piperacillin MIC against a clinical isolate of $P$. aeruginosa, OU1, that exhibits multidrug resistance against aztreonam, cefepime, ceftazidime, ciprofloxacin, Meropenem, and piperacillin/tazobactam (see the Supporting Information). The MIC of piperacillin (64 $\mu \mathrm{g} / \mathrm{mL})$ is resistant, but $2 \mu \mathrm{g} / \mathrm{mL} 600 \mathrm{Da}$ BPEI $(3.3 \mu \mathrm{M})$ reduces the $\beta$-lactam MIC to 4 $\mu \mathrm{g} / \mathrm{mL}$, which is interpreted as susceptibility. 
Growth Curve of $P$. aeruginosa BAA-47

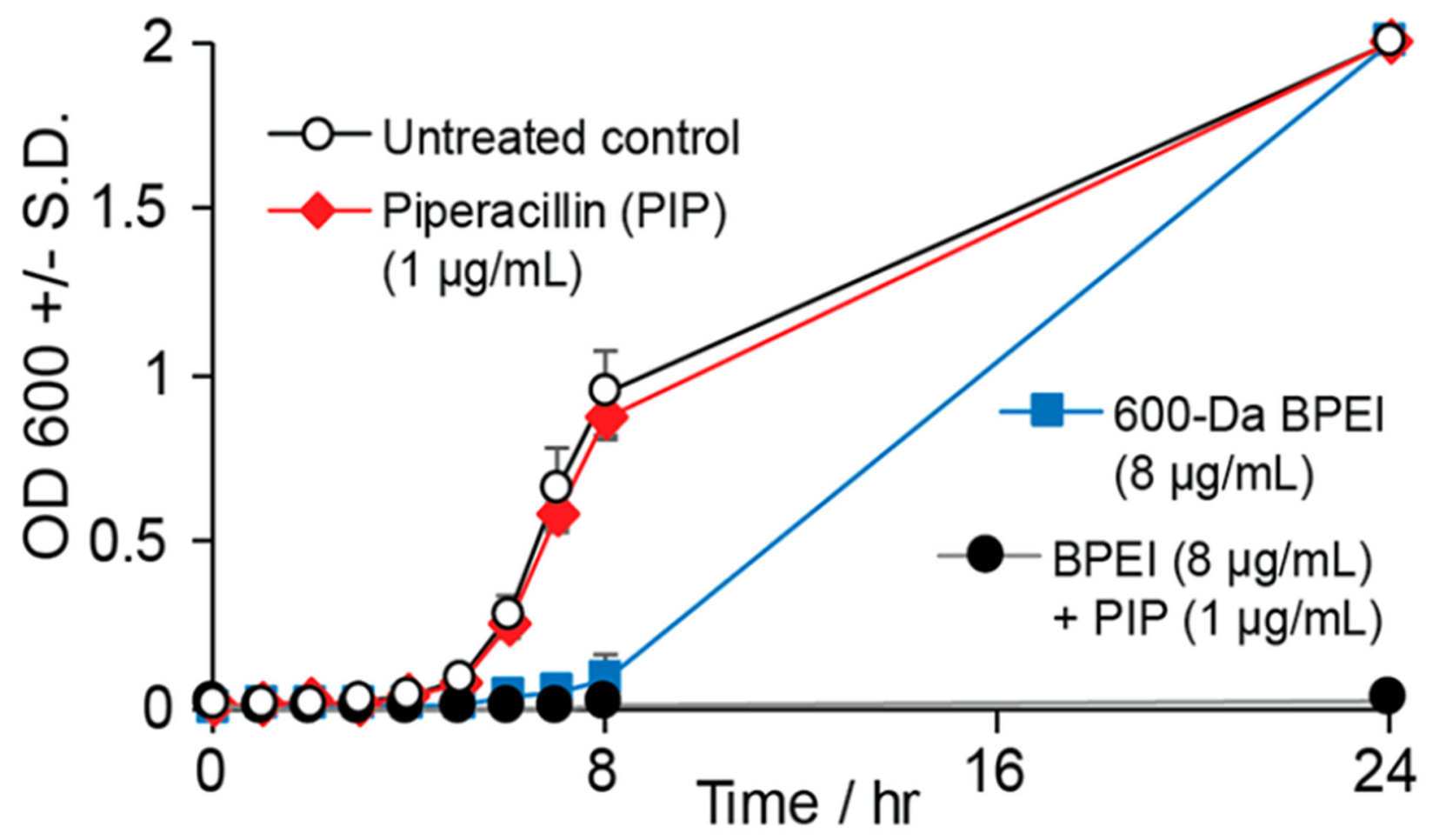

Figure 3.

Growth curves of PA BAA-47 show that sublethal amounts of 600 Da BPEI and piperacillin slow bacterial growth but do not kill the culture. However, treating the culture with a combination of $600 \mathrm{Da}$ BPEI and piperacillin, each at sublethal concentrations, stops growth. Error bars denote standard deviation $(n=2)$ and, for some data points, are smaller than the data symbol. 
A. ITC data from mixing BPEI with $P$. aeruginosa LPS

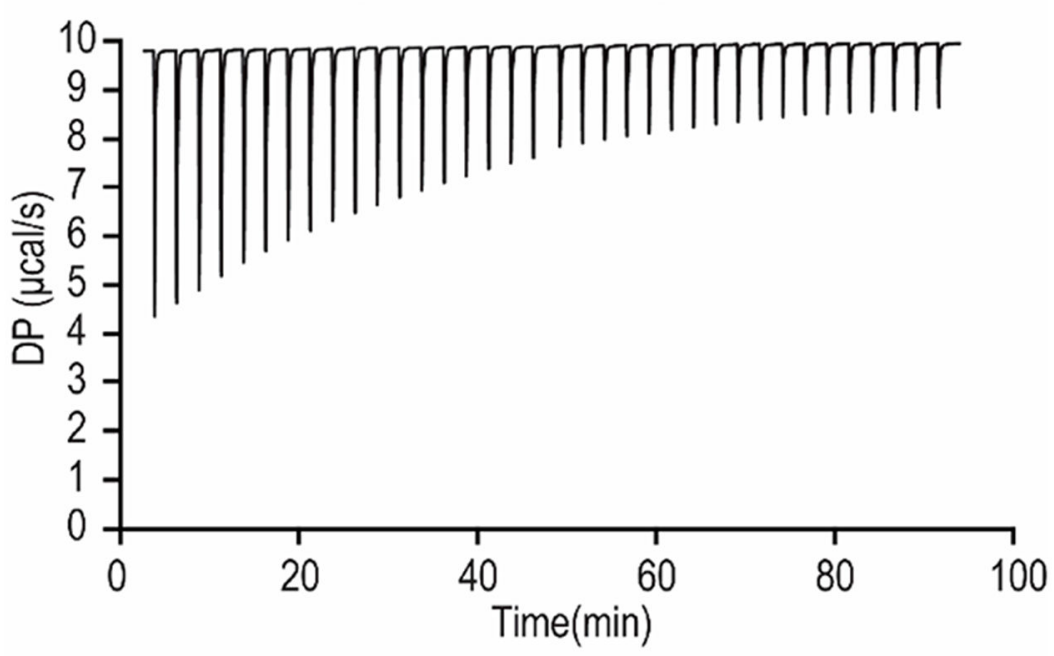

B. Thermogram presentation of the ITC data

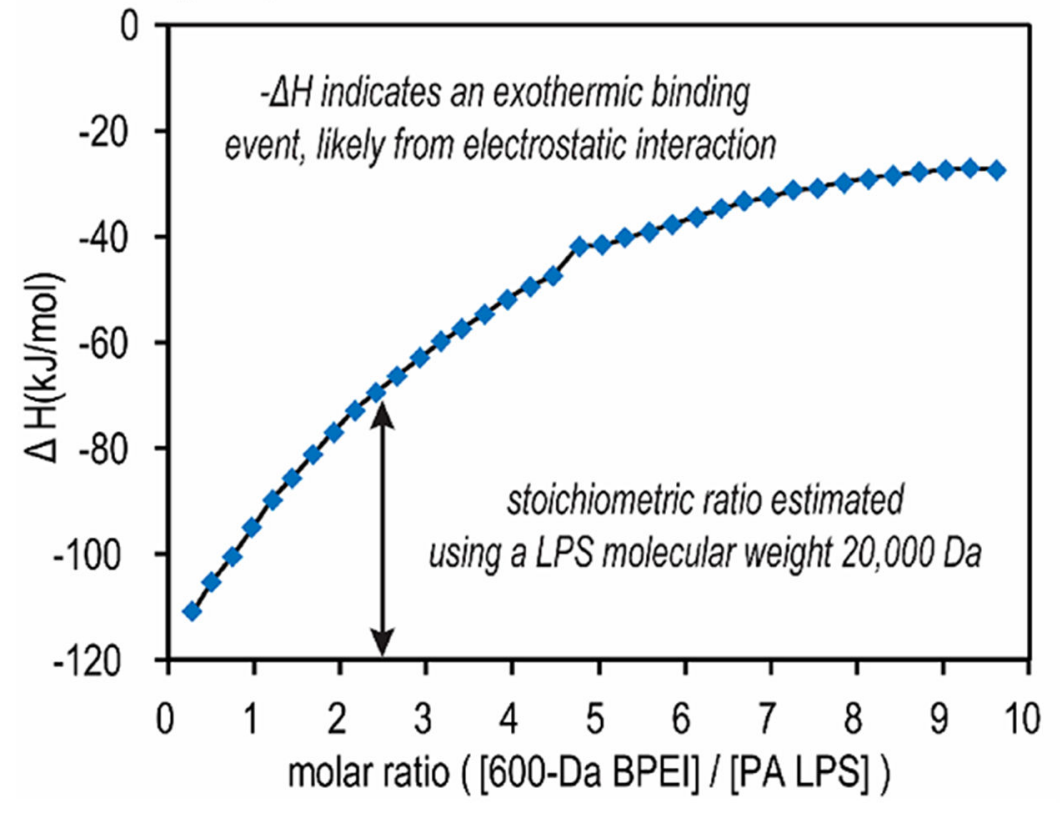

Figure 4.

(A) Raw ITC data of 600 Da BPEI interacting with P. aeruginosa LPS. 600 Da BPEI (0.64 $\mathrm{mg} / \mathrm{mL}$ ) was titrated into LPS $(5 \mathrm{mg} / \mathrm{mL})$ via $2 \mu \mathrm{L}$ injections in $50 \mathrm{mM}$ Tris- $\mathrm{HCl}(\mathrm{pH} 7)$ buffer at $25^{\circ} \mathrm{C}$. The raw data in (A) indicate an exothermic binding event, which can be quantified by conversion to an ITC thermogram (B). The thermogram abscissa is generated from the molar ratio of each species. Here, the molecular mass of LPS was estimated to be $20 \mathrm{kDa}$ in accordance with literature reports. ${ }^{27}$ 
600-Da BPEl affects the outer membrane in a concentration dependent manner

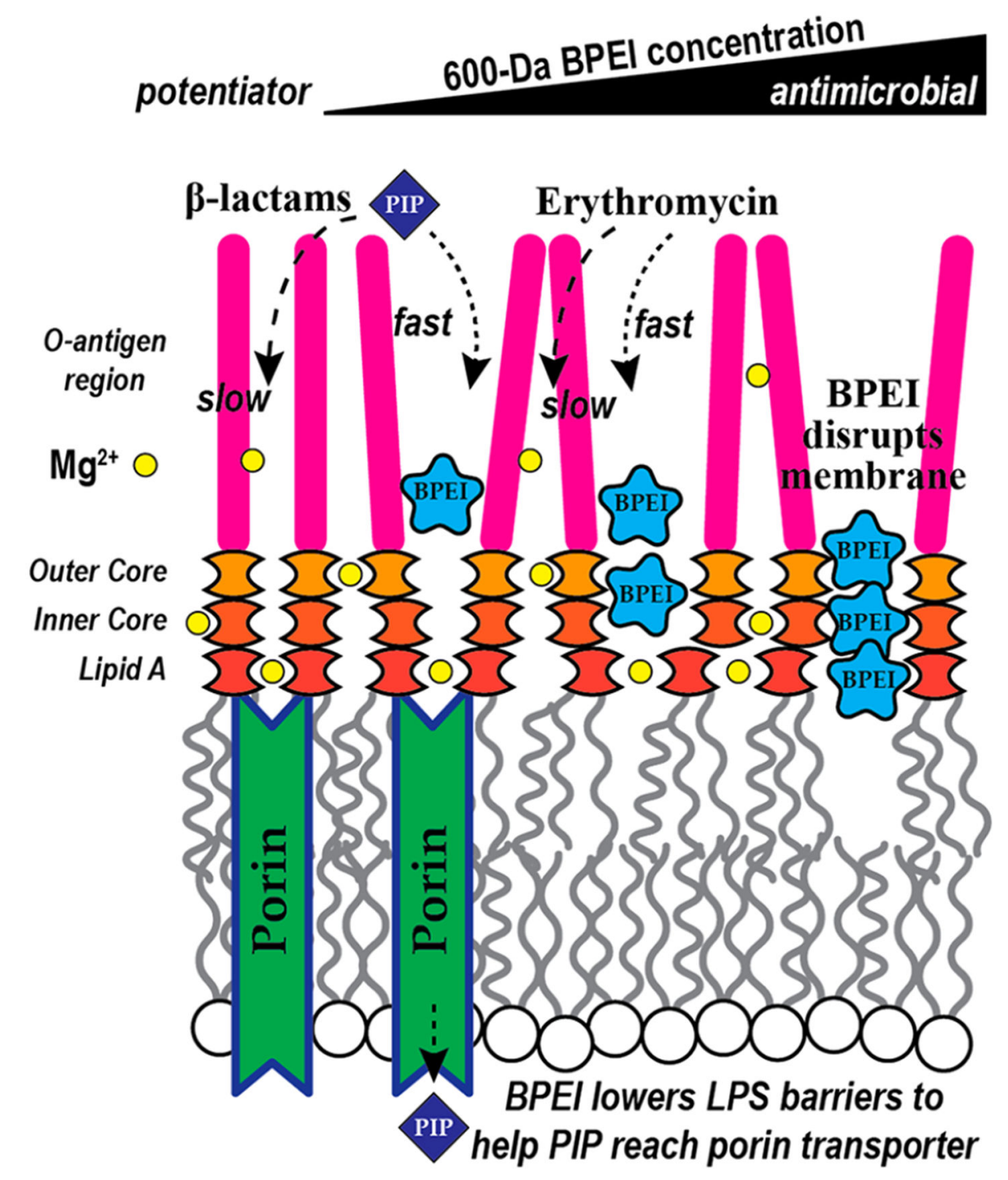

Figure 5.

Illustration of how 600 Da BPEI binds to LPS and facilitates the passive diffusion of $\beta$ lactams toward porin transporters. Higher concentrations are required to increase the uptake of non- $\beta$-lactams (such as erythromycin), and at the highest concentration, 600 Da BPEI exhibits its own antibacterial properties. 


\section{0-Da BPEI Increases Passive Influx}

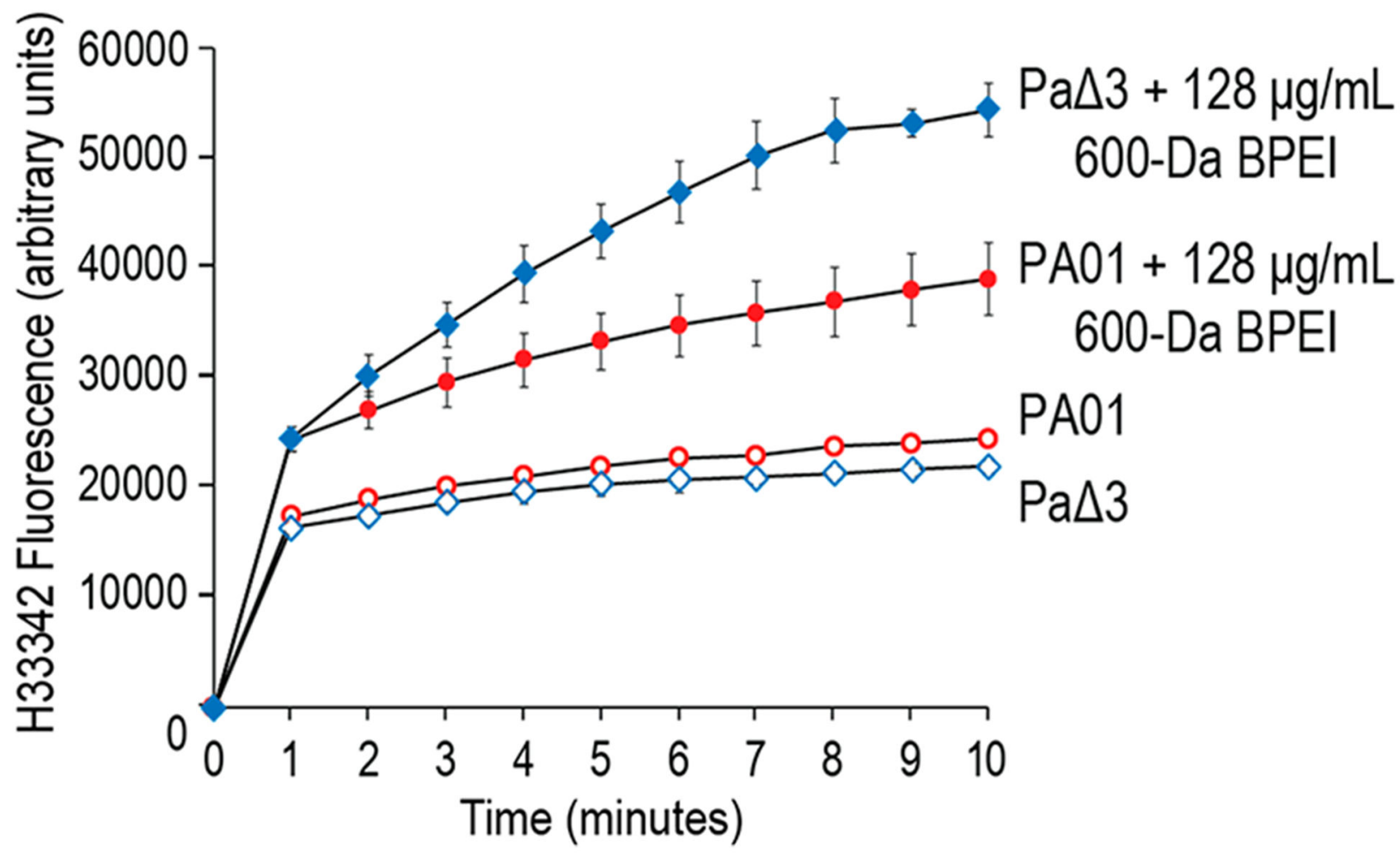

Figure 6.

Effect of 600 Da BPEI on the intracellular accumulation of the DNA-binding H33342 in a $P$. aeruginosa PAO1 strain with drug resistance. ${ }^{32}$ Real-time kinetics of H33342 uptake show that 600 Da BPEI significantly increased the H33342 accumulation (closed red circles) into the bacterial cells, compared to the untreated control (open red circles). Similar effects are seen with the efflux deficient mutant $\mathrm{Pa} \Delta 3$ (open and closed blue diamonds). The intracellular concentration of $\mathrm{H} 33342$ in the treated cells is higher than the wild-type cells, indicating that $600 \mathrm{Da}$ BPEI does not hinder efflux processes. Error bars denote standard deviation $(n=5)$. 
Concentration Dependence of Increasing Influx
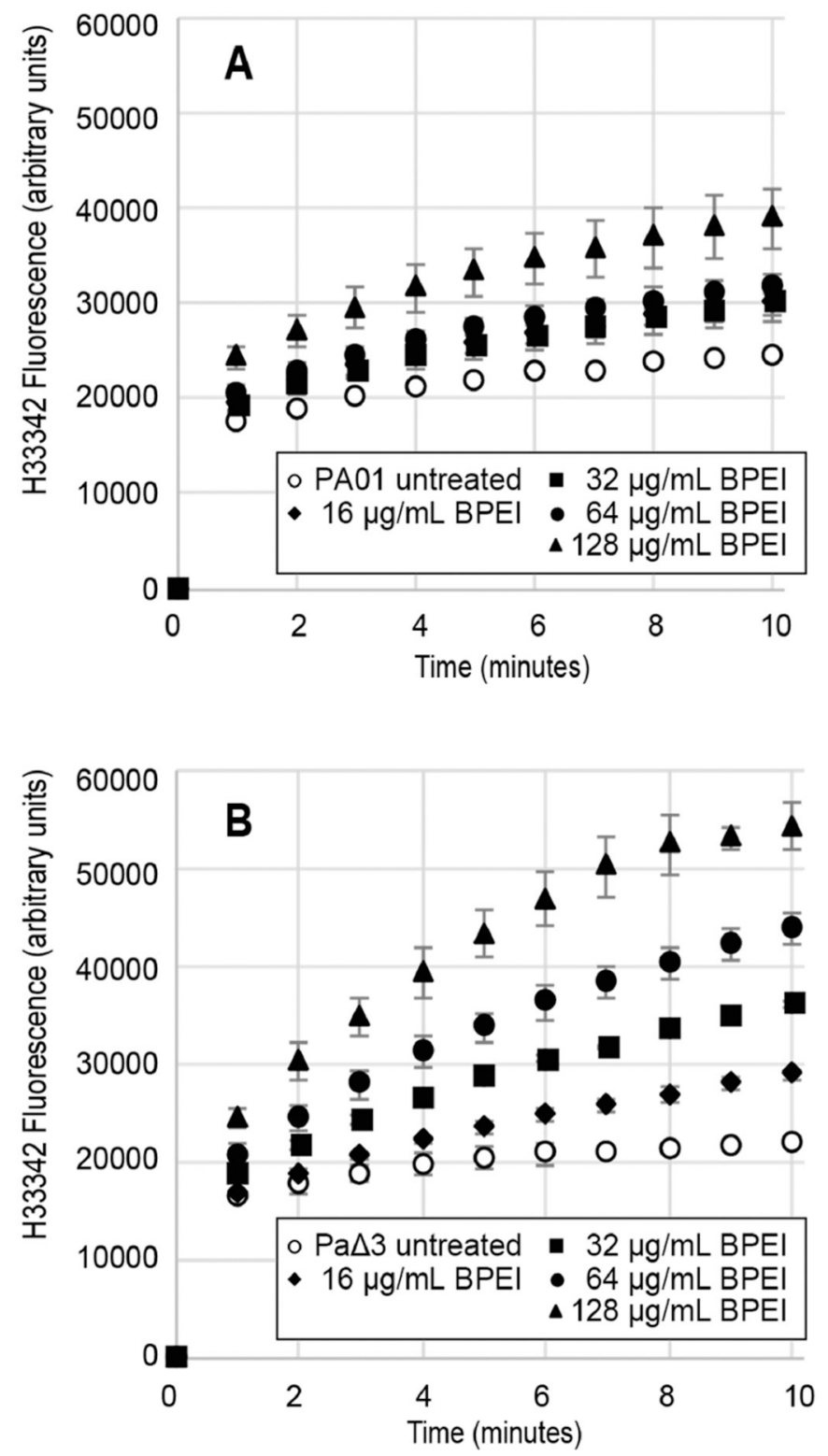

Figure 7.

(A) Concentration dependence of the $\mathrm{H} 33342$ concentration in the wild-type PAO1 cell. Competition between influx and efflux processes in the viable cells results in overlapping data points. In the efflux-deficient mutant strain (B), higher concentrations of $600 \mathrm{Da}$ BPEI result in higher dye concentrations $(n=5)$. 


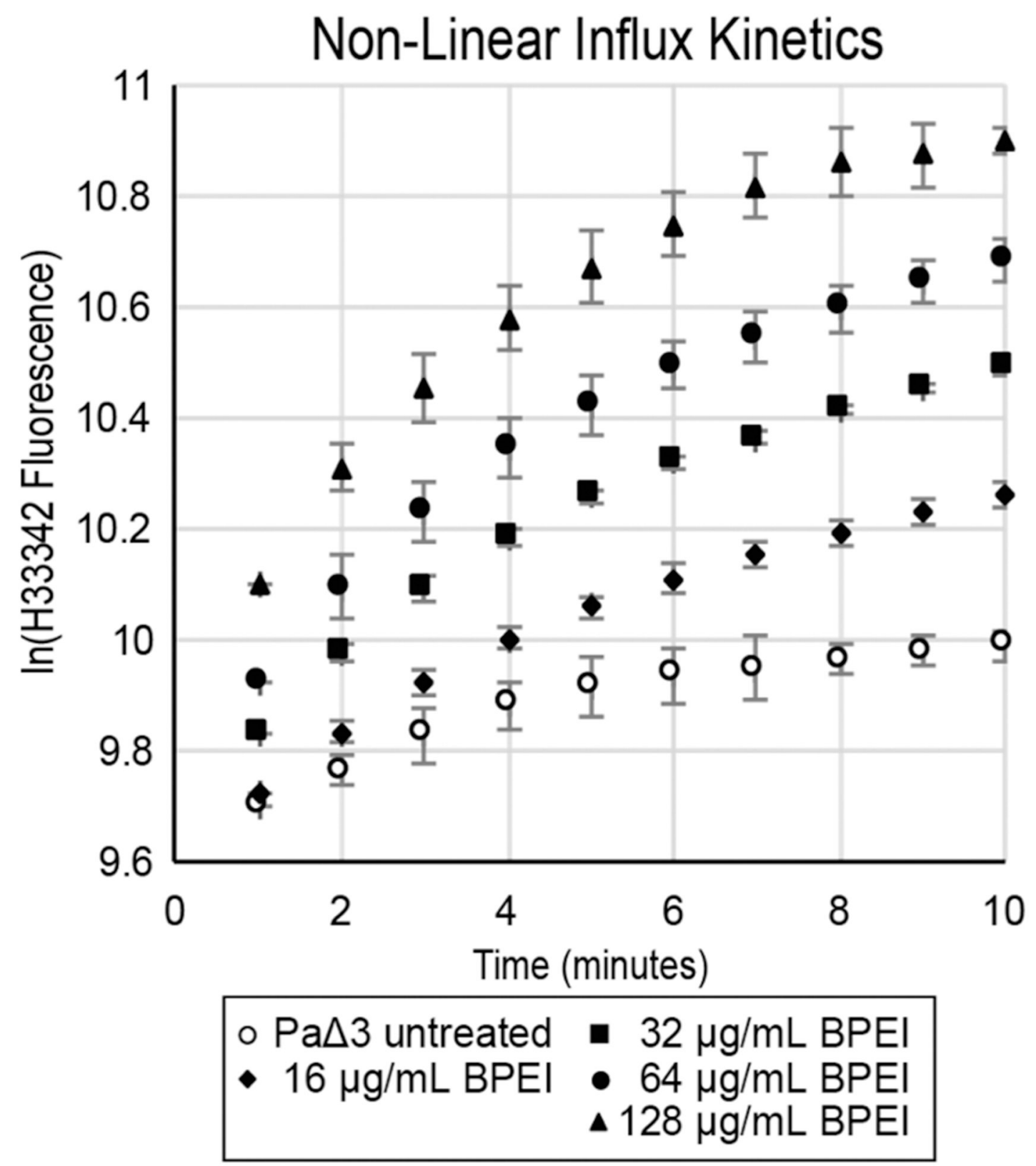

Figure 8.

Uptake of H33342 is a multistep process with exponential kinetics. This phenomenon can be identified by plotting the natural logarithm of dye concentration versus time. The increasing slope with concentration shows that the rate of influx increases as the passive diffusion barriers are lowered from 600 Da BPEI binding to additional anionic sites on LPS molecules (see Figure S7). 


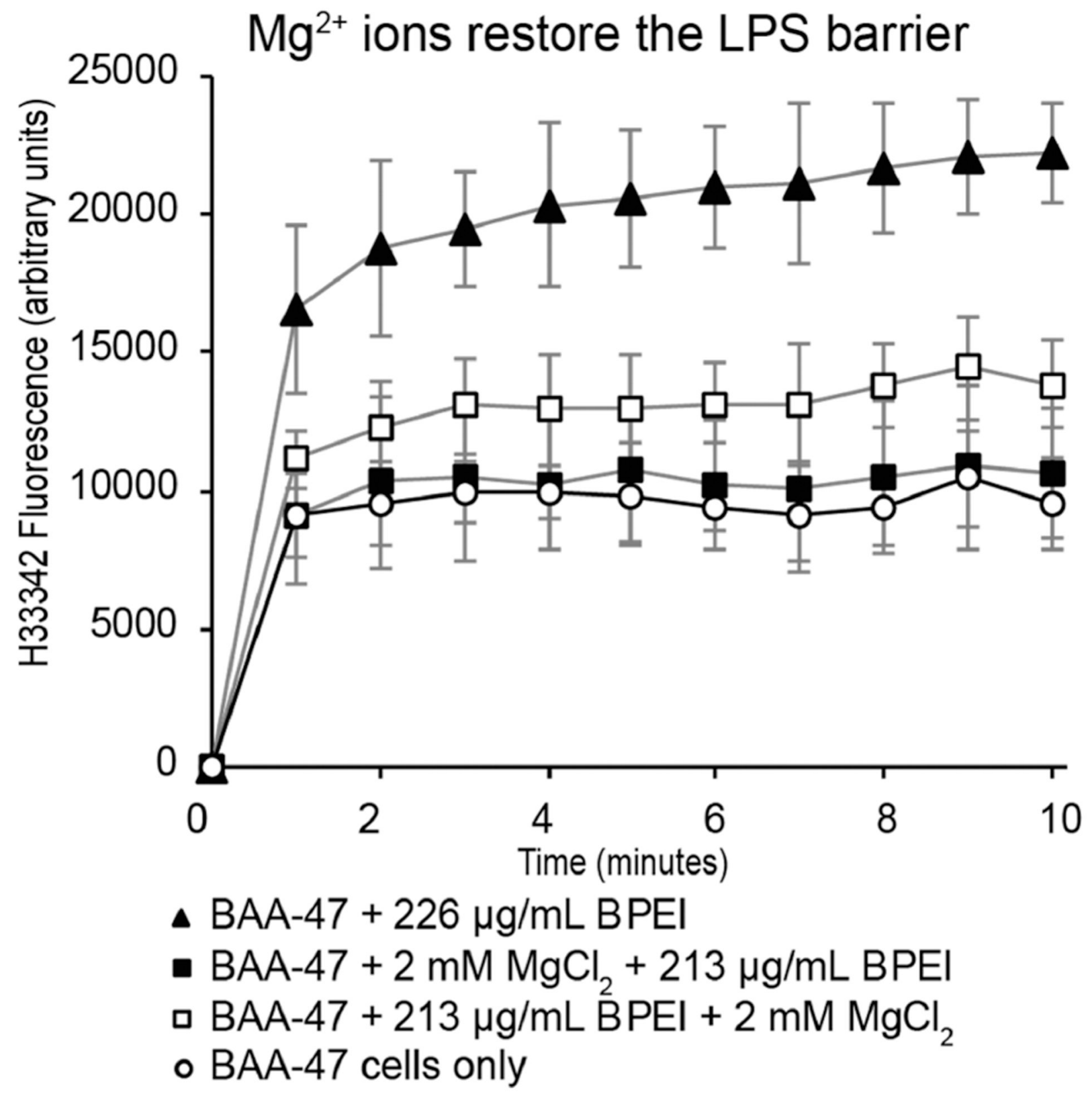

Figure 9.

BPEI binds to LPS through anionic sites on the inner-core, outer-core, and O-antigen regions. These sites also bind divalent metal ions. The growth media contains trace amounts of metal ions, and thus, the anionic regions of LPS are not fully occupied. This provides an opportunity for 600 Da BPEI to bind with LPS and increase H33342 influx (triangles) compared to untreated cells (open circles). However, adding $2 \mathrm{mM} \mathrm{MgCl} 2$ to BPEI-treated cells results in a reduction of dye influx (open squares) as the metals ions occupy the remaining anionic sites and restore LPS barriers to diffusion. Likewise, if the metal ions are added first (closed squares), all LPS anionic sites are occupied, preventing the binding of $600 \mathrm{Da}$ BPEI that would otherwise increase dye influx. $n=5$. 


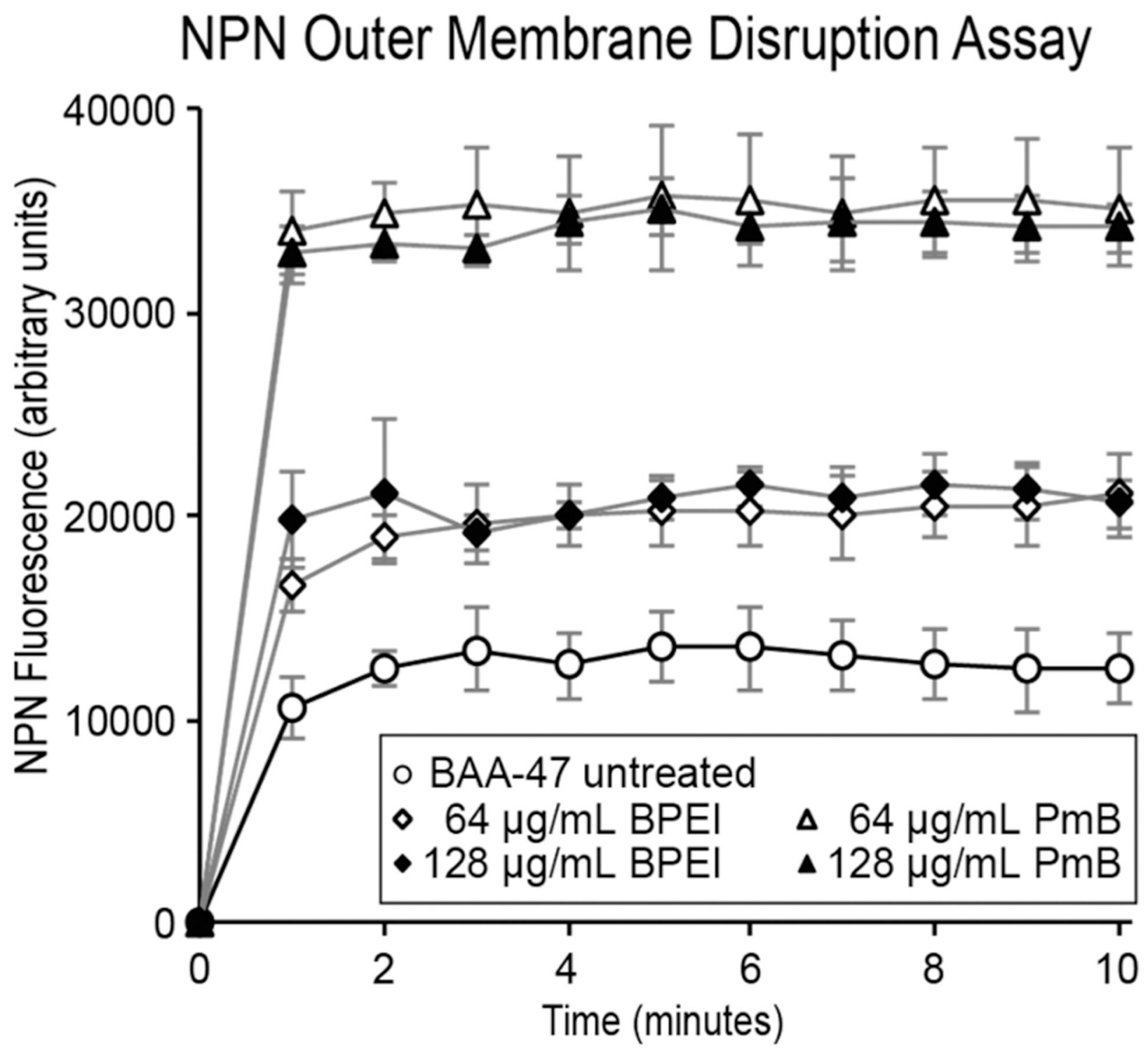

Figure 10.

Dye $1-N$-phenylnaphthylamine (NPN) accumulates in hydrophobic regions and fluoresces when bound to phosphate groups. Polymyxin B (PmB) allows greater uptake of NPN than 600 Da BPEI. The sublethal concentrations of 600 Da BPEI allow NPN access to the membrane without affecting cell viability, as determined from the resazurin assay data in Figure S6. However, polymyxin B kills the bacterial cells (Figure S6) because the cell membranes are disrupted. The paradigm of $600 \mathrm{Da}$ BPEI increasing drug influx without membrane disruption is illustrated in Figure S11. $n=5$. 

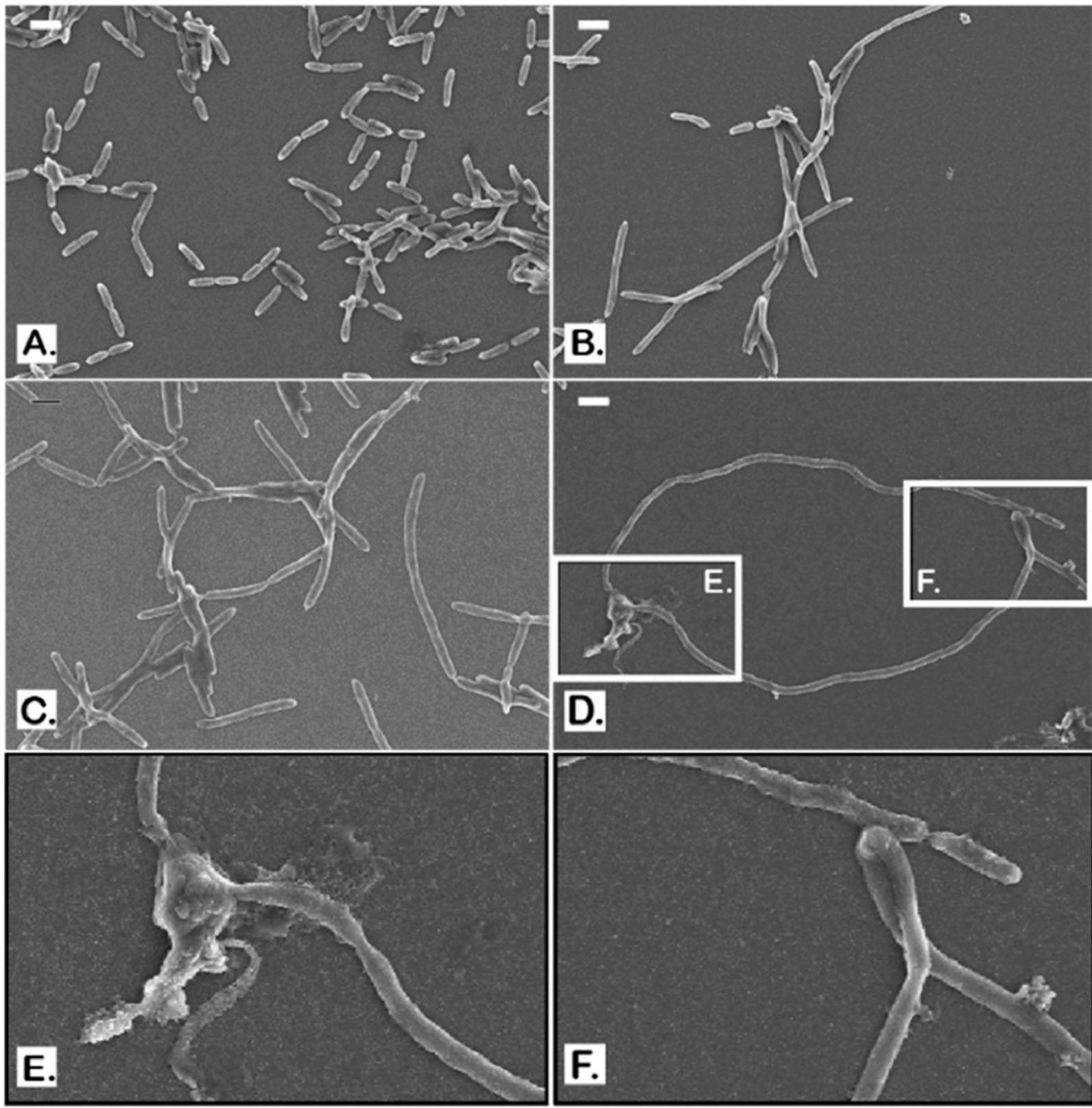

Figure 11.

Scanning electron micrograph images of PA BAA-47. Untreated control cells appear with a regular rod shape of about 2-3 $\mu \mathrm{m}$ long (A). 600 Da BPEI treated cells $(4 \mu \mathrm{g} / \mathrm{mL})$ (B) and piperacillin treated cells $(1 \mu \mathrm{g} / \mathrm{mL})(\mathrm{C})$ show inconsistency in their size with longer lengths, but the rod shape remains. The combination of $4 \mu \mathrm{g} / \mathrm{mL} 600 \mathrm{Da}$ BPEI $+1 \mu \mathrm{g} / \mathrm{mL}$ piperacillin treated cells (D) show extreme distortions in both size and shape with insets (E) and (F) for higher magnifications. Scale bars $=2 \mu \mathrm{m}$. 


\section{P. aeruginosa BAA-47 Biofilm MBEC Assay}
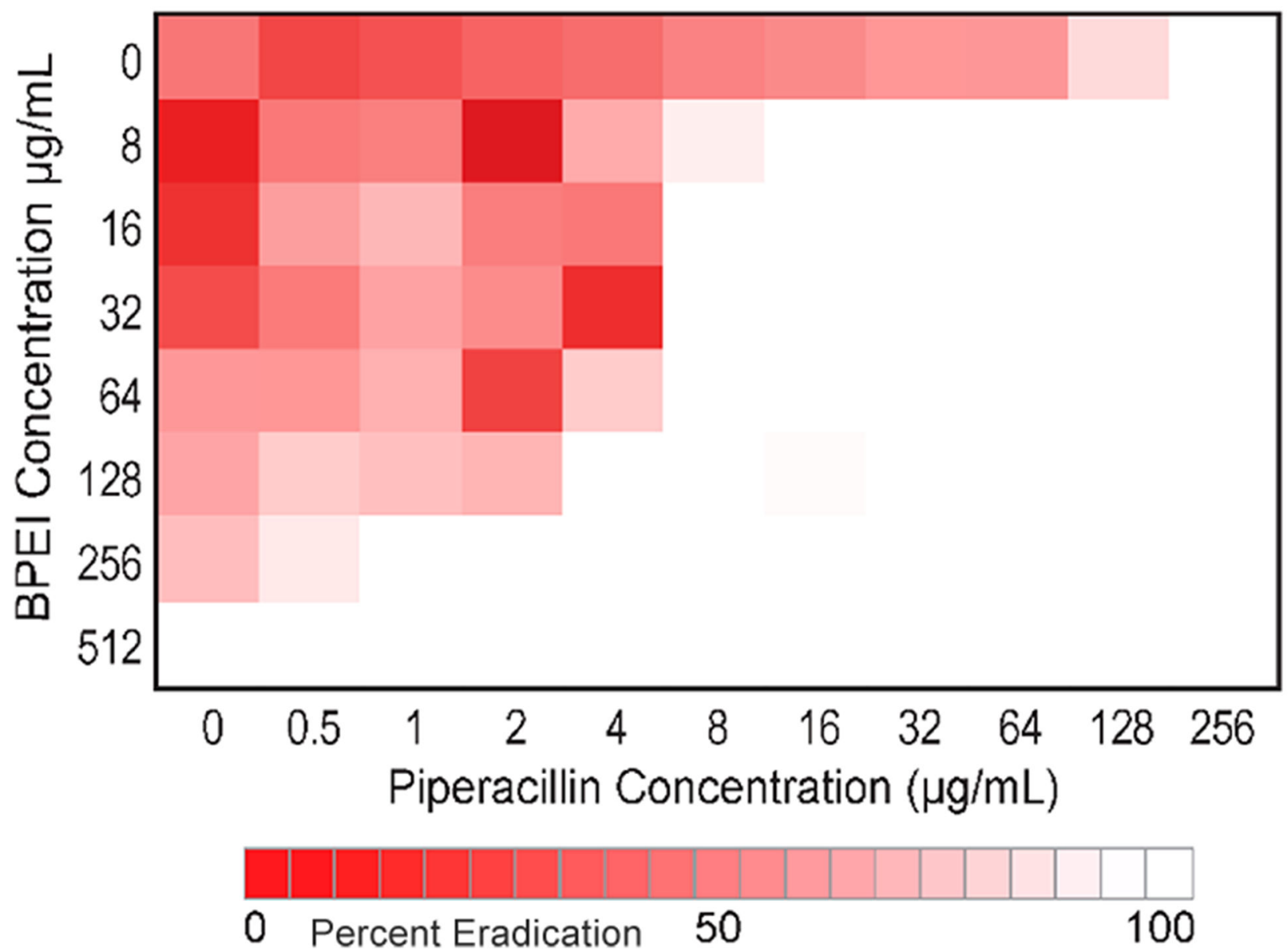

Figure 12.

Biofilm eradication assay data collected with the Calgary biofilm device. ${ }^{57}$ EPS creates additional barriers to piperacillin efficacy, and thus, $256 \mu \mathrm{g} / \mathrm{mL}$ is required to kill the bacteria. However, $600 \mathrm{Da}$ BPEI disrupts the biofilm EPS and increases $\beta$-lactam access to the cells, reducing the MBEC to $8 \mu \mathrm{g} / \mathrm{mL}$. 

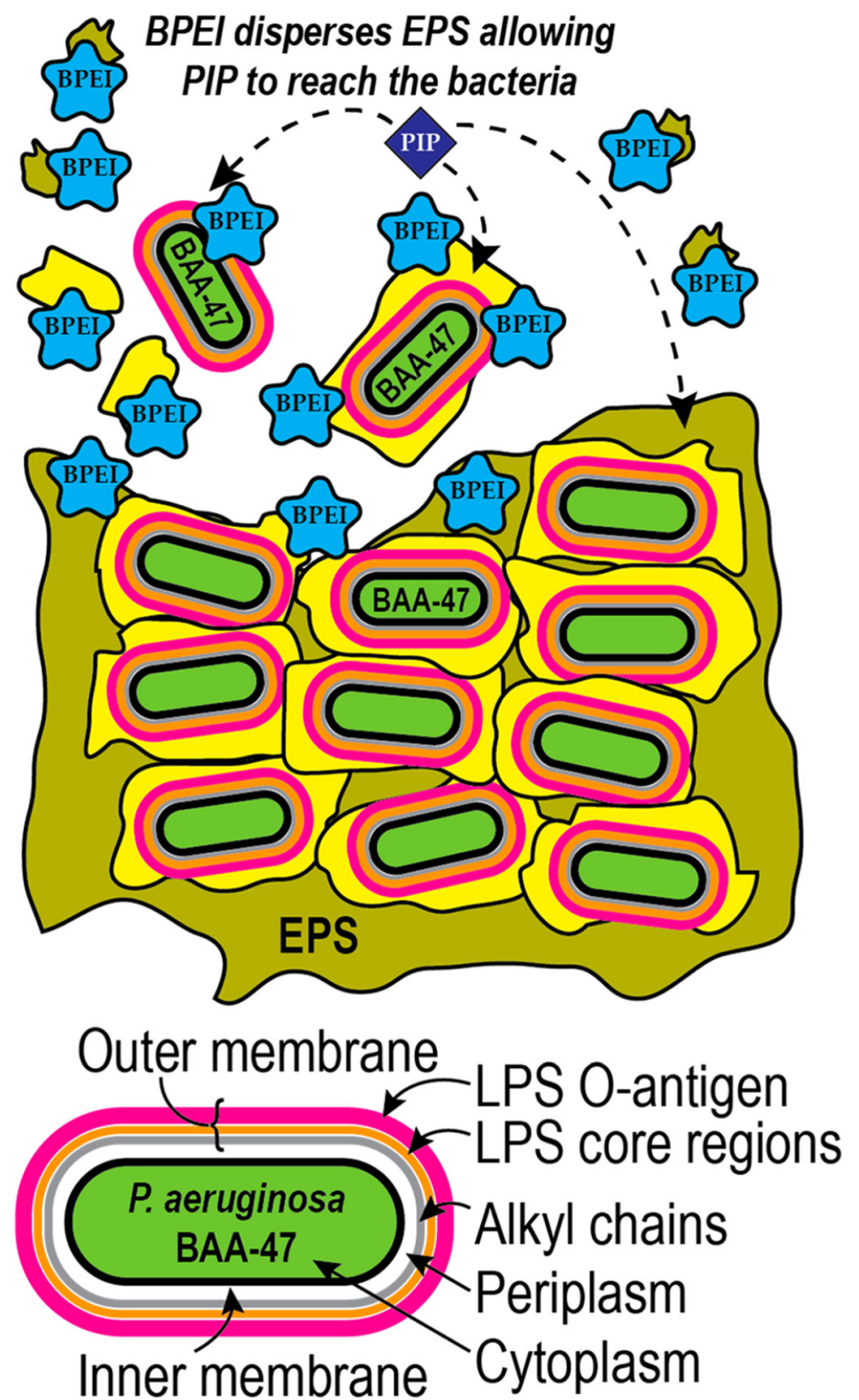

Figure 13.

Illustration of 600 Da BPEI binding to and dispersing the exopolymeric substances (EPSs) of $P$. aeruginosa BAA-47 bacteria. The dispersal of the EPSs allows antibiotics, such as piperacillin (PIP), to reach the bacteria and kill them. The presence of $600 \mathrm{Da}$ BPEI also enables the reduction of the LPS diffusion barrier to potentiate antibiotic efficacy. 


\section{를 \\ 골}

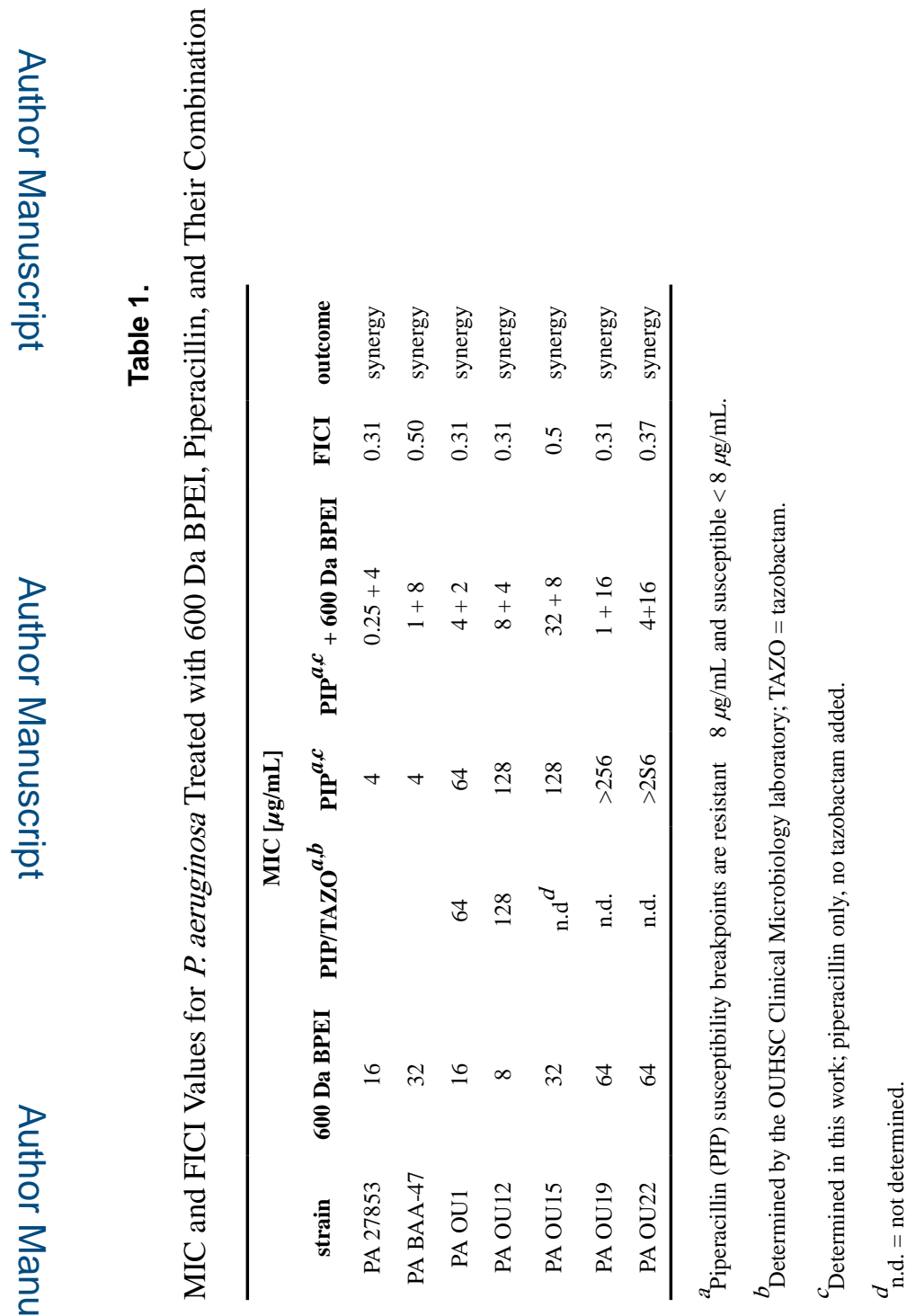

ACS Infect Dis. Author manuscript; available in PMC 2020 May 18. 